\title{
HMGA2 as a Critical Regulator in Cancer Development
}

\author{
Behzad Mansoori ${ }^{1,2,3,4} \mathbb{D}$, Ali Mohammadi 1,3 ${ }^{\text {, Henrik J. Ditzel }}{ }^{3,5,6} \mathbb{D}^{\mathbb{D}}$, Pascal H. G. Duijf ${ }^{7,8} \mathbb{D}$, Vahid Khaze ${ }^{1,3}$, \\ Morten F. Gjerstorff $3,5,6, *$ (D) and Behzad Baradaran $1, *$ (D)
}

1 Immunology Research Center, Tabriz University of Medical Sciences, Tabriz 51656-65811, Iran; b.mansoori_lab@yahoo.com (B.M.); amohammadi@health.sdu.dk (A.M.); shahgoli@health.sdu.dk (V.K.)

2 Student Research Committee, Tabriz University of Medical Sciences, Tabriz 51656-65811, Iran

3 Department of Cancer and Inflammation Research, Institute for Molecular Medicine,

University of Southern Denmark, 5230 Odense, Denmark; hditzel@health.sdu.dk

4 Aging Research Institute, Physical Medicine and Rehabilitation Research Center,

Tabriz University of Medical Sciences, Tabriz 51656-65811, Iran

5 Department of Oncology, Odense University Hospital, 5000 Odense, Denmark

6 Academy of Geriatric Cancer Research (AgeCare), Odense University Hospital, 5000 Odense, Denmark

7 Institute of Health and Biomedical Innovation, School of Biomedical Sciences, Faculty of Health,

Queensland University of Technology, Brisbane, QLD 4102, Australia; p.duij@@uq.edu.au

8 University of Queensland Diamantina Institute, The University of Queensland, Brisbane, QLD 4102, Australia

* Correspondence: mgjerstorff@health.sdu.dk (M.F.G.); baradaranb@tbzmed.ac.ir (B.B.)

Citation: Mansoori, B.; Mohammadi,

A.; Ditzel, H.J.; Duijf, P.H.G.; Khaze,

V.; Gjerstorff, M.F.; Baradaran, B.

HMGA2 as a Critical Regulator in

Cancer Development. Genes 2021, 12,

269. https://doi.org/10.3390/

genes12020269

Academic Editor: Félix Machín

Received: 7 January 2021

Accepted: 8 February 2021

Published: 13 February 2021

Publisher's Note: MDPI stays neutral with regard to jurisdictional claims in published maps and institutional affiliations.

\begin{abstract}
The high mobility group protein 2 (HMGA2) regulates gene expression by binding to AT-rich regions of DNA. Akin to other DNA architectural proteins, HMGA2 is highly expressed in embryonic stem cells during embryogenesis, while its expression is more limited at later stages of development and in adulthood. Importantly, HMGA2 is re-expressed in nearly all human malignancies, where it promotes tumorigenesis by multiple mechanisms. HMGA2 increases cancer cell proliferation by promoting cell cycle entry and inhibition of apoptosis. In addition, HMGA2 influences different DNA repair mechanisms and promotes epithelial-to-mesenchymal transition by activating signaling via the MAPK/ERK, TGF $\beta$ /Smad, PI3K/AKT/mTOR, NFkB, and STAT3 pathways. Moreover, HMGA2 supports a cancer stem cell phenotype and renders cancer cells resistant to chemotherapeutic agents. In this review, we discuss these oncogenic roles of HMGA2 in different types of cancers and propose that HMGA2 may be used for cancer diagnostic, prognostic, and therapeutic purposes.
\end{abstract}

Keywords: HMGA2; cancer; cell cycle; apoptosis; DNA repair; MAPK; TGF $\beta$; RKIP; miRNA

\section{Introduction}

High mobility group (HMG) proteins are nonhistone, chromatin-associated molecules involved in maintenance and functional regulation of DNA, including the processes of replication, recombination, transcription, and DNA repair [1]. The proteins of this superfamily bend DNA upon binding to the minor groove and thereby contribute to transcriptional regulation and maintenance of the chromatin structure [2]. HMG proteins have extremely broad DNA sequence specificity, therefore supplying an exceptional mechanism for protein-DNA interactions [3]. The biological activities of HMG proteins are regulated through epigenetic mechanisms, which affect their interactions with DNA and other transcription factors. Consequently, this affects signaling pathways by recruitment of different transcription factors to the target gene promotors, which cause a specific phenotypic outcome.

The HMG superfamily is grouped into three main families, including HMGA, HMGB and HMGN. The HMGA gene family consists of two functional members, high mobility group A1 (HMGA1or HMGI/Y) and high mobility group A2 (HMGA2 or HMGI-C). HMGA proteins bind to AT-rich DNA regions that exist in short stretches in the minor groove of the DNA (Figure 1) [4]. In addition to DNA, they also interact with different 
proteins, such as E2 promoter-binding factor $1(\mathrm{E} 2 \mathrm{~F} 1)$ and retinoblastoma protein $(\mathrm{Rb})$. Increasing evidence indicates that HMGA proteins do not directly regulate transcriptional activity, but rather control gene expression by changing chromatin structure and organizing several transcription factors on a so-called "enhanceosome" [5,6]. When HMGA2 binds to AT-rich hooks of DNA, the conformation changes from disordered to ordered, and in turn this introduces bending, unwinding, straightening, and looping of DNA [7]. The acidic tail of the HMGA2 protein is responsible for protein-protein interactions. Thus, this domain mediates binding of HMGA2 to other DNA binding proteins, such as transcription factors [8].
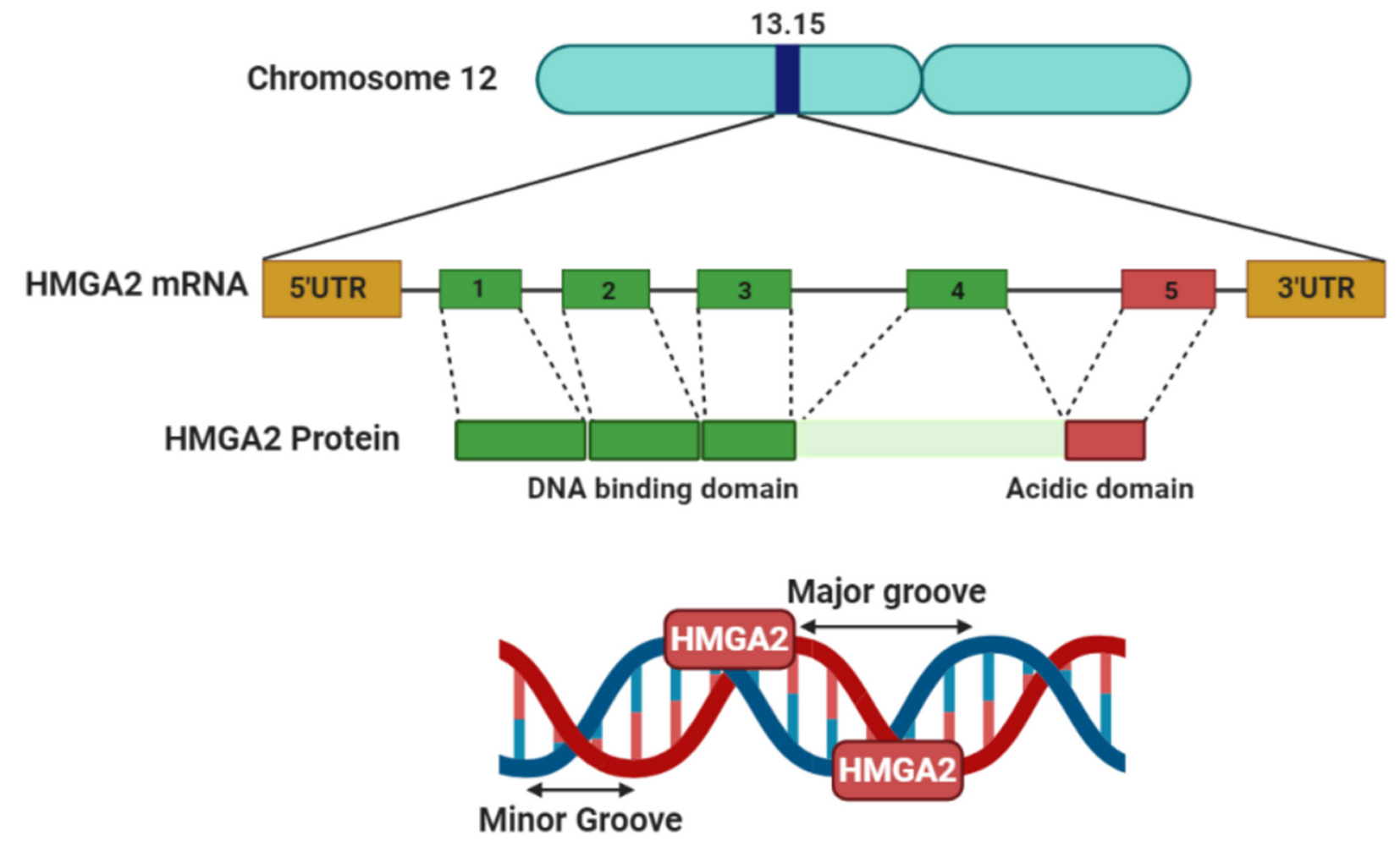

Figure 1. Schematic of the high mobility group protein 2 (HMGA2) gene and protein. Located on chromosome 12, the HMGA2 gene encodes a small protein, which can bind to AT-rich sites in the minor groove of DNA and subsequently regulate transcription by inducing conformational changes to the DNA.

Recent studies suggest a possible link between HMG proteins and cancer development $[9,10]$. HMGA2 is important during early embryogenesis and is highly expressed during oncogenesis. Studies have shown that HMGA2 increases cancer progression through the activation of several pathways. In this literature review, we highlight the oncogenic role of HMGA2 in tumor development and progression and discuss the probable signaling pathways affected by this architectural protein.

\section{HMGA2 Structure and Function}

The HMGA2 gene contains five exons distributed over a genomic area of more than $140 \mathrm{~kb}$ located at human chromosome 12q13-15 (Figure 1). The first three exons encode the AT-binding domain site, while exon 4 encodes a protein linker and exon 5 the acidic domain which does not activate transcription (Figure 1). HMGA2 is a rather small protein of less than $12 \mathrm{kDa}$, comprising 108 amino acids. Akin to the other protein family members, HMGA2 regulates gene expression by binding to the DNA minor groove and chromatin management [11].

The HMGA2 AT-binding domains are each comprised of nine amino acids, including the invariable repeat Arg-Gly-Arg-Pro [12]. During transcription, these domains can bind 
to B-shaped DNA and convert it from disordered to ordered conformations. Based on the number and location of the AT-rich binding sites, HMGA2 affects the conformation of DNA in several ways. By influencing the structure of DNA, it can change its effect on transcription by enhancing or suppressing the activities of numerous genes, consequently affecting various biological processes [6].

HMGA2 is widely expressed in undifferentiated cells during early development and embryogenesis, but expression becomes more restricted as fetal development progresses. During late development and adulthood, it is expressed in kidney, liver, and uterus [13], while the expression is low in lung and kidney [14]. Importantly, HMGA2 is re-expressed in a variety of benign and malignant tumors including breast, lung, ovarian, colorectal, and pancreatic cancers [15-17] (Figure 2). A full genome analysis showed that HMGA2 is preferentially expressed by stem cells and that displayed a progressive decay in expression with age, partly due to increasing let-7b microRNA expression [18]. Furthermore HMGA2 expression has been limited to the mesenchyme during normal development [19]. The role of HMGA2 in adipogenesis, spermatogenesis, and stem cell development has been proved in in vivo experiments in an HMGA2 null mice model [20].

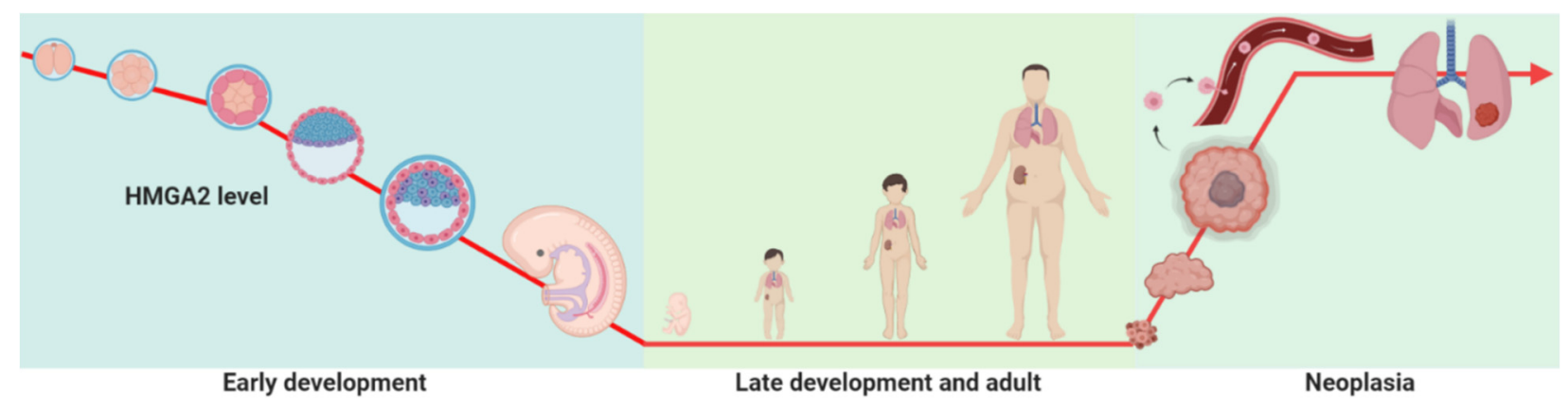

Figure 2. HMGA2 expression level during development and neoplasia. HMGA2 is highly expressed during early embryonic development. In contrast, in late development and during adulthood, the expression levels of this are low. However, the expression of HMGA2 is increased during the development of cancer.

HMGA2 has been implicated in DNA translocations in lipomas and mesenchymal tumors. These generate chimeric transcripts in which exons 4 and 5 may be substituted by a wide range of other coding sequences such as Snail1, Snail2, and Twist, lead to binding of HMGA2 to a variety of genes with three AT-hooks [21]. These HMGA2 fusion proteins can both inhibit and activate gene expression by modifying chromatin arrangement, and some HMGA2 fusion proteins have been demonstrated to cause tumorigenicity. A truncated form of HMGA2 with only the three AT-binding domains and without an acidic domain was sufficient for transformation in vitro [22]. This finding supports other work showing that the acidic domain is not critical for triggering tumorigenicity [23]. Both full-length and 3'UTR truncated HMGA2 in transgenic mice develop benign mesenchymal tumors, including breast fibroadenomas and salivary gland adenomas [24]. Injection of HMGA2 overexpressing fibroblasts into athymic nude mice formed fibrosarcomas and metastases [25]. Furthermore, another study reported that both full-length and truncated HMGA2 induce the development of various benign tumors in mesenchymal tissues such as breast fibroadenoma, salivary gland adenoma, and preputial gland hyperplasia, suggesting that misexpression of HMGA2 itself is sufficient for tumorigenicity in this cell linage [24]. Recently, new insights into the role of HMGA2 translocations in tumorigenesis were provided. It was reported that a translocation leading to a reduction in the $3^{\prime}$ UTR of HMGA2 might increase tumorigenicity [26]. HMGA2 has a long UTR (about 3000 nucleotides), which renders this mRNA amenable to regulation by multiple microRNAs (miRNAs). Reverse association of these miRNA and HMGA2 is crucial for regulatory mechanisms in both normal tissue development and tumorigenesis [26]. The hypothesis that miRNAs could regulate HMGA2 expression, as well as other oncogenes, was firstly confirmed by 
DICER knockdown in HeLa cells [26]. More recent studies identified various miRNAs which could regulate HMGA2 expression at the post-transcriptional level during oncogenesis by targeting the HMGA2 $3^{\prime}$ UTR. These include the let-7 family [27], miR-330 [28], miR-98-5p [29], miR-33-5p [30], miR-34a-5p [31], miR-497 [32], and miR-491 [33].

\section{HMGA2 Overexpression in Cancer}

HMGA2 is aberrantly regulated in a broad range of human cancers, including lung [34], breast [35], and ovarian cancers [36] and increased expression of HMGA2 correlates with a higher risk of cancer progression. Comparing cancer to normal tissues by RNA-seq showed varying HMGA2 expression patterns in different types of cancers (Table 1). According to the datasets existing in the Oncomine cancer profiling database (www.oncomine.org, accessed on 7 Febuary 2021), HMGA2 is generally more highly expressed in sarcoma, brain and CNS, esophageal, head and neck, lung, melanoma, ovarian, and pancreatic cancers compared to corresponding normal tissue. In contrast, lower expression of HMGA2 was found in colorectal and gastric cancers, leukemia, and lymphoma (Table 1). In breast and prostate cancers, varying expression levels were observed in different studies (Table 1).

Table 1. HMGA2 expression changes in different cancer types. Data compare cancer tissues to normal tissues. The cut-offs including $p$-value $=0.01$, fold change $=1.5$, and gene ranking $=10 \%$.

\begin{tabular}{|c|c|c|c|c|c|}
\hline Cancer & HMGA2 Status & Sample Size & Fold Change & $p$-Value & Reference \\
\hline $\begin{array}{l}\text { Bladder } \\
\text { cancer }\end{array}$ & Down & 60 & -1.576 & $5.55 \times 10^{-8}$ & [37] \\
\hline $\begin{array}{l}\text { Brain and } \\
\text { CNS cancer }\end{array}$ & Up & 85 & 21.74 & $8.16 \times 10^{-5}$ & [38] \\
\hline \multirow{3}{*}{ Breast cancer } & Up & 593 & 1.58 & $1.14 \times 10^{-4}$ & TCGA \\
\hline & $\mathrm{Up}$ & 66 & 1.57 & 0.003 & [39] \\
\hline & Down & 59 & -23.054 & $1.58 \times 10^{-23}$ & [40] \\
\hline $\begin{array}{l}\text { Colorectal } \\
\text { cancer }\end{array}$ & Down & 40 & -2.51 & $1.15 \times 10^{-6}$ & [41] \\
\hline \multirow{2}{*}{$\begin{array}{c}\text { Esophageal } \\
\text { cancer }\end{array}$} & $\mathrm{Up}$ & 34 & 5.093 & $5.32 \times 10^{-6}$ & {$[42]$} \\
\hline & UP & 106 & 1.785 & $1.06 \times 10^{-10}$ & [43] \\
\hline $\begin{array}{l}\text { Gastric } \\
\text { cancer }\end{array}$ & Down & 132 & -1573 & 0.001 & {$[44]$} \\
\hline \multirow{8}{*}{$\begin{array}{l}\text { Head and } \\
\text { neck cancer }\end{array}$} & UP & 99 & 2.045 & $2.05 \times 10^{-6}$ & [45] \\
\hline & UP & 18 & 6.098 & $3.11 \times 10^{-5}$ & [46] \\
\hline & UP & 38 & 3.657 & $7.34 \times 10^{-7}$ & [47] \\
\hline & UP & 18 & 9.926 & $6.31 \times 10^{-6}$ & [48] \\
\hline & UP & 20 & 2.877 & 0.001 & [49] \\
\hline & UP & 54 & 2.368 & $2.06 \times 10^{-7}$ & [50] \\
\hline & UP & 84 & 3.781 & $2.45 \times 10^{-5}$ & [51] \\
\hline & $\mathrm{UP}$ & 41 & 2.130 & $5.93 \times 10^{-5}$ & [52] \\
\hline Leukemia & Down & 293 & -2.087 & 0.005 & [53] \\
\hline \multirow{4}{*}{ Lung cancer } & $\mathrm{Up}$ & 66 & 2.320 & $3.18 \times 10^{-5}$ & {$[54]$} \\
\hline & Up & 246 & 3.001 & $1.39 \times 10^{-12}$ & [55] \\
\hline & $\mathrm{Up}$ & 73 & 3.999 & 0.005 & [56] \\
\hline & Up & 156 & 11.019 & $1.01 \times 10^{-10}$ & [57] \\
\hline Lymphoma & Down & 136 & -1.798 & $1.14 \times 10^{-11}$ & [58] \\
\hline Melanoma & $\mathrm{Up}$ & 87 & 2.664 & $8.13 \times 10^{-4}$ & [59] \\
\hline $\begin{array}{l}\text { Ovarian } \\
\text { cancer }\end{array}$ & $\mathrm{Up}$ & 594 & 2.965 & $1.16 \times 10^{-5}$ & TCGA \\
\hline
\end{tabular}


Table 1. Cont.

\begin{tabular}{cccccc}
\hline Cancer & HMGA2 Status & Sample Size & Fold Change & $p$-Value & Reference \\
\hline $\begin{array}{c}\text { Pancreatic } \\
\text { cancer }\end{array}$ & Up & 52 & 3.629 & $1.17 \times 10^{-7}$ & {$[60]$} \\
\hline Prostate & Up & 15 & 126.524 & $1.15 \times 10^{-7}$ & {$[61]$} \\
cancer & Down & 35 & -4.150 & $9.90 \times 10^{-6}$ & {$[62]$} \\
\hline Sarcoma & Down & 102 & -1.681 & 0.007 & {$[63]$} \\
\hline
\end{tabular}

TCGA: The Cancer Genome Atlas Program.

In addition to RNA-seq analyses, several studies that analyzed HMGA2 levels by IHC, Western blotting, and qRT-PCR found increased HMGA2 expression during cancer development. Previously, we demonstrated increased HMGA2 expression in breast tumor tissues compared to normal tissues [35,65]. Other studies showed that HMGA2 is overexpressed in lung [66,67], ovarian [36], breast [68], colorectal [69], pancreatic [70], gastric [71], prostate [72], bladder [73], tongue [74], pituitary [75], and thyroid [76] cancers. In contrast, one study reported that HMGA2 expression is reduced in nasopharyngeal cancer [77].

\section{Regulation of HMGA2 by miRNAs in Cancer}

miRNAs are master gene expression regulators at the post-transcriptional level. These small regulatory molecules bind to the $3^{\prime}$ UTRs of specific target mRNAs. An endonuclease complex accumulates at the bound region. Consequently, the complex cleaves a target mRNA from the binding region or suppresses mRNA translation by trapping it in processing bodies (p-bodies) [78,79]. HMGA2 has a long $3^{\prime} \mathrm{UTR}$, therefore providing a long targeting region for different miRNAs. Indeed, interactions of miRNAs with specific target mRNA is predicted using different databases, including miRanda, Pictar, miRTarbase and TargetScan. Let-7 downregulation and HMGA2 overexpression occur during lung cancer development. The let-7 family of miRNAs were the first reported miRNAs targeting the $3^{\prime}$ UTR of HMGA2 and degrading HMGA2 mRNA [26]. Various databases predict eight putative target sites for let-7. Stimulation of HMGA2 influences the other family member, HMGA1. This induces miR-196a via a negative feedback loop that suppresses HMGA2 [80,81] (Figure 3).

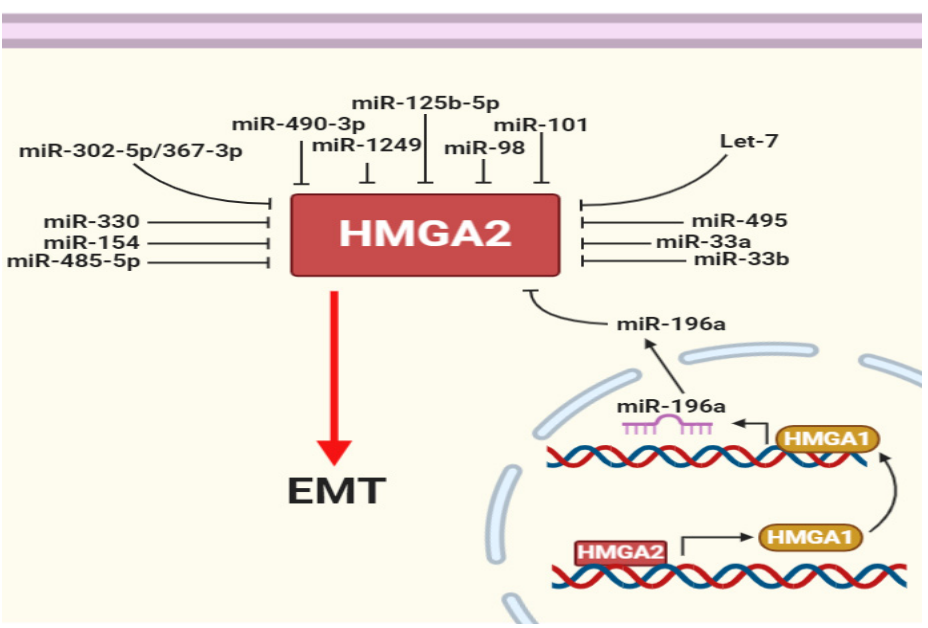

Figure 3. HMGA2 is regulated by multiple microRNAs. HMGA2 regulates itself by promoting HMGA1 and then HMGA1 decreased HMGA2 by increasing miR-196a. In addition, several microRNAs (miRNAs) have been shown to repress epithelial-mesenchymal transition (EMT) by targeting HMGA2. 
In our recent study, we showed that miR-330 targets HMGA2 and stable induction of $m i R-330$ expression inhibits Snail1 and increases E-cadherin expression in breast cancer cells [28]. Other studies have demonstrated that a range of other miRNAs, including miR-101 [82], miR-98 [83], miR-302a-5p/367-3p [84], miR-1249 [85], miR-490-3p [86], miR-125b-5p [87], miR-495 [87], miR-485-5p [88], miR-33a [89], miR-33b [90], and miR-154 [72], target HMGA2 and reduce epithelial-mesenchymal transition (EMT) in cells in which these miRNAs are induced (Figure 3). In mouse xenografts, it was further shown that HMGA2 promotes breast tumor growth, survival, and metastasis by inducing syndecan-2 (SDC2) via a $m i R-200$-independent mechanism [91].

\section{HMGA2 Induce Cancer Proliferation}

HMGA2 influences the expressions of a broad spectrum of genes, many of which are involved in cancer cell proliferation and survival [92]. In this section, we discuss the mechanisms of HMGA2 in regulating cell proliferation with insights into the role of HMGA2 in the cell cycle, apoptosis and DNA damage repair.

\subsection{HMGA2 Increase Cancer Cell Proliferation by Directing Cell Cycle}

Uncontrolled cell cycle progression promotes neoplastic transformation. It was shown that increased HMGA2 expression in cancer supports cell proliferation by accelerating cell cycle progression. In accordance with this, HMGA2 silencing leads to cell cycle arrest in different phases of the cell cycle. For example, HMGA2 knockdown arrests cells in the G1 phase in ovarian cancer [36], but in the G2/M phase in leukemia [93]. In earlier studies, we demonstrated G2/M arrest in both breast and colorectal cancer in response to HMGA2 knockdown $[35,94]$. The direct binding of HMGA2 to the cyclic adenosine monophosphate (cAMP)-responsive component of cyclin A2 dislocates p120E4F complexes from cyclic AMP-responsive element (CRE), and accelerates the binding of the ATF/CREB complex to enhance cell cycle progression $[95,96]$. Furthermore, the activator protein-1 (AP1) complex, composed of Jun (JUN, JUNB, and JUND), FOS (FOS, FOSB, and FRA1) and FRA2 proteins, is crucial for the regulation of cell proliferation [97] and downregulation of HMGA2 inhibits the expression of JUNB and FRA1 completely [98]. In contrast, increased expression of HMGA2 enhances expression of these genes [98]. Moreover, HMGA2-mediated promotion of AP1 increases the expression of cyclin A2 to support cell cycle progression [98].

By interactions with E2F1 transcription factors, the pRB precisely regulates cell cycle entry into the $S$ phase [99] (Figure 4A). Before cells enter the $S$ phase, pRB phosphorylation and its inactivation cause E2F1 release, resulting in S phase entry [100]. It has further been demonstrated that HMGA2 supports the role of E2F1 as a transcription factor by dislocating histone deacetylase 1 (HDAC1) from E2F1 target promoters [75] (Figure 4A). The two most important cyclin-dependent kinase inhibitors (CDKIs) which restrict release of E2F1 from $\mathrm{pRB}$ are P16INK4A and p21CIP1/WAF1. Interestingly, HMGA2 overexpression directly activates the $\mathrm{PI} 3 \mathrm{~K} / \mathrm{AKT} / \mathrm{mTOR} / \mathrm{p} 70 \mathrm{~S} 6 \mathrm{~K}$ signaling pathway, resulting in cyclin E activation and inhibition of p16INK4A and p21CIP1/WAF1 activities [101]. Additionally, RB phosphorylation is accelerated by the activation of cyclin D1/CDK4/CDK6 and HMGA2 supports the cyclin D1 synthesis [102]. This suggests that HMGA2 also influences cell cycle progression via the cyclin D1/CDK4/CDK6/pRB-E2F1 axis [103,104] (Figure 4A). In addition, HMGA2 could regulate cyclin B2 expression by binding to the promoter of the CCNB2 gene and increasing its expression, thereby promoting G2/M transition and cell proliferation $[105,106]$. 


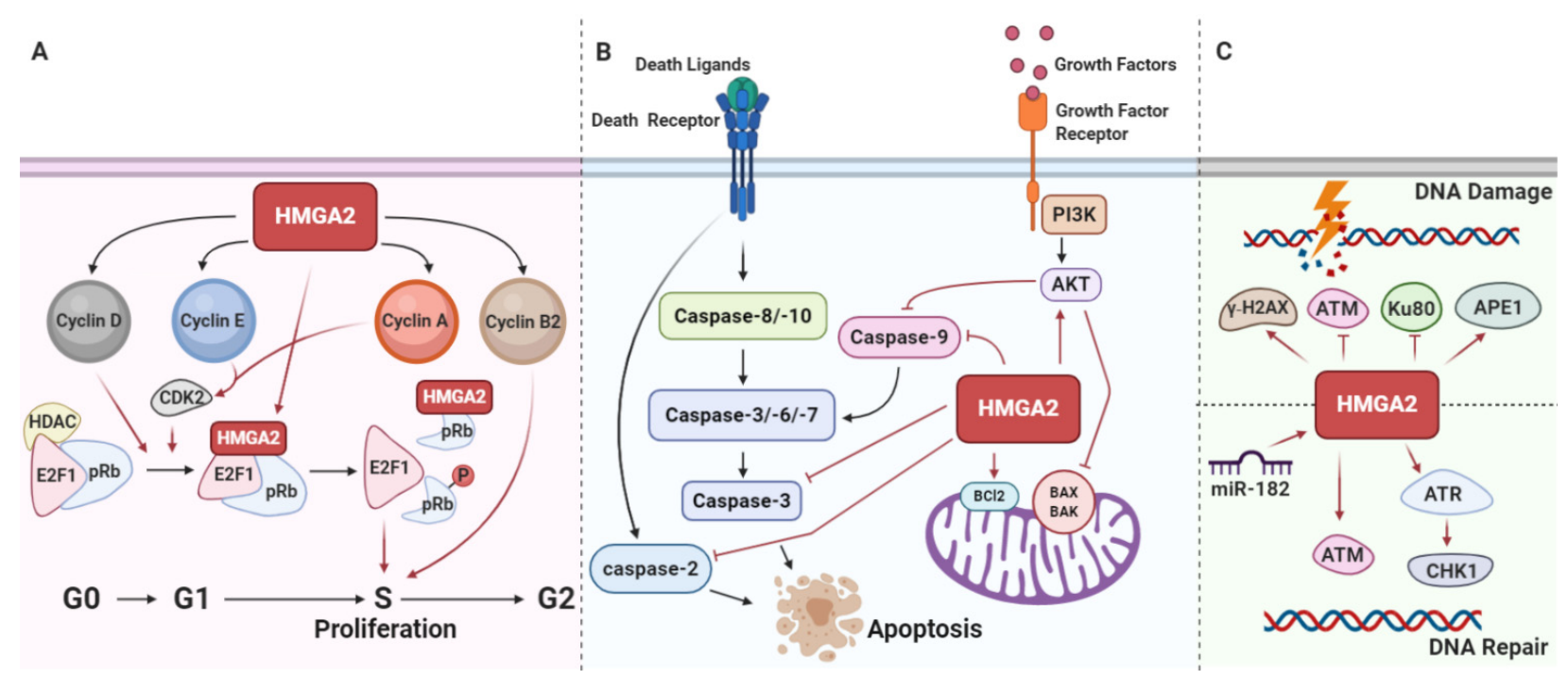

Figure 4. HMGA2 promotes cancer cell proliferation, inhibits apoptosis, and differentially affects DNA damage repair. (A) HMGA2 activates cyclin D1, cyclin E, and cyclin A and promotes pRB phosphorylation. This releases E2 promoterbinding factor 1 (E2F1), enabling it to induce transcription of target genes that promote $S$ phase entry. HMGA2 directly activates E2F1 by replacing histone deacetylase 1 (HDAC1) from pRB. HMGA2 also triggers proliferation by inducing cyclin B2. (B) HMGA2 negatively regulates proapoptotic proteins, including caspase-2, -3 , and -9, and induces antiapoptotic Bcl2. HMGA2 also promotes AKT signaling, which suppresses BAX/BAK and caspase-9 activation. (C) HMGA2 triggers $\gamma$-H2AX and human AP endonuclease 1 (APE1) and inhibits Ku-80 and ataxia telangiectasia mutated protein (ATM), thereby promoting DNA damage. In contrast, by activating ATM, ataxia telangiectasia, and Rad3-related kinase (ATR), and checkpoint kinase 1 (CHK1), HMGA2 also promotes DNA repair. miR-182 is an oncogenic miRNA that promotes DNA repair by inducing HMGA2.

\subsection{HMGA2 Protects Cancer Cells from Apoptosis}

There is considerable evidence that HMGA2 can inhibit apoptosis in tumor cells and promote tumor growth. Tumors with high HMGA2 expression exhibit high proliferation and low apoptosis rates compared to tumors with low HMGA2 expression $[65,107,108]$ and a mechanism for HMGA2 regulation of apoptosis has been proposed. It was shown that HMGA2 silencing promotes apoptosis by reducing antiapoptotic Bcl-2 expression in ovarian cancer [34] and we found that HMGA2 derepresses the expression of Bcl-2 by inhibiting miR-34a in breast cancer, thereby promoting the Bcl-2 antiapoptotic pathway [65]. Furthermore, there is positive feedback between the expression of Bcl-2 and HMGA2, as overexpression of $\mathrm{Bcl}-2$ increases the expression of HMGA2 in thyroid cells [107]. The $\mathrm{PI} 3 \mathrm{~K} / \mathrm{AKT}$ signaling pathway is often hyperactivated in human cancer and this contributes to resistance to apoptosis [108]. Activated AKT inhibits apoptosis by reducing caspase-9 and BAD activation $[109,110]$. Importantly, HMGA2 suppresses apoptosis by activating PI3K/AKT signaling, thereby reducing caspase-9 and BAD activation [111] (Figure 4B). Additionally, phosphorylation of ataxia telangiectasia and Rad3-related kinase (ATR)/CHK1 is considerably decreased during apoptosis. It has been shown that repression of HMGA2 inhibits the ATR/checkpoint kinase 1 (CHK1) signaling pathway, resulting in apoptosis [112]. In addition, silencing of TNF-related apoptosis-inducing ligand-R2 (TRAIL-R1) considerably enhances the level of let-7 and this decreases HMGA2 expression [113].

Intriguingly, apoptotic effects of HMGA2 have also been described. Caspase-2 promotes the release of cytochrome from mitochondria, which is essential for the induction of apoptosis [114]. Therefore, it is of interest that induction of HMGA2 expression upregulates levels of cleaved caspase-2, thereby inducing apoptosis [115] (Figure 4B). In another study, HMGA2 was implicated in inducing apoptosis by triggering 6-O-methylguanine-associated DNA damage [116]. Altogether, the above findings specify both anti- and proapoptotic roles of HMGA2. 


\subsection{HMGA2 Is Involved in DNA Damage and Repair Responses}

HMGA2 influences the DNA repair process by controlling multiple DNA repairassociated proteins. It was demonstrated that HMGA2 possesses intrinsic apurinic/ apyrimidinic (AP) site cleavage activity [117]. A physical interaction between human AP endonuclease 1 (APE1) and HMGA2 in cancer cells was demonstrated, which supports the involvement of HMGA2 in the base excision repair (BER) machinery [117]. HMGA2 has a positive and/or negative effect on nonhomologous end-joining (NHEJ). HMGA2 suppresses NHEJ and impairs DNA-PK dynamics by altering Ku70 and Ku80 binding to DNA ends [118]. HMGA2 caused the persistence of $\gamma-\mathrm{H} 2 \mathrm{AX}$, which may disrupt NHEJ. On the other hand, HMGA2 enhances NHEJ by activating the ataxia telangiectasia mutated protein (ATM) [119]. HMGA2 acts as a substrate for ATM and its downstream tumor suppressor checkpoint kinase 2 (CHK2), which are crucial for DNA damage signaling. Exposure to genotoxic radiation or chemicals, such as UV irradiation and peroxide $\left(\mathrm{H}_{2} \mathrm{O}_{2}\right)$, increases the expression of HMGA2, which correlates with enhanced ATM expression and an increased DNA damage response [120]. In addition, interaction between HMGA2 and the ataxia telangiectasia and Rad3-related kinase (ATR) promotes ATR-checkpoint kinase 1 (CHK1) signaling pathway activation, which in turn induces G2/M cell cycle arrest. This promotes chemoresistance against alkylation-induced genotoxicity in different types of human cancer [121]. In addition, there is some evidence to show that, during DNA damage, HMGA2 expression induces and subsequently sustains ATR and CHK1 levels, which prolongs $\mathrm{G} 2 / \mathrm{M}$ arrest and enhances tumor cell survival in different human tumors with high HMGA2 expression [121] (Figure 4C).

It has been shown that protein phosphatase 4 regulatory subunit 1 (PP4R1) regulates centrosome maturation, DNA repair, apoptosis, and tumor necrosis factor (TNF) signaling. It was reported that PP4R1 could cooperate with HMGA2 and promote EMT through activating MAPK/ERK signaling pathway in lung cancer cells [122]. HMGA2 could promote nucleotide excision repair by binding to the AT-rich site located 298-323 upstream of the excision repair cross-complementation group 1 (ERCC1) gene transcription start site [123]. Oncogenic miR182 impairs DNA double-strand breaks repair; it may do this through downregulation of BRCA1 and MTSS1 and upregulation of HMGA2 and $\gamma H 2 A X$ expression (Figure 4C) [124].

\subsection{HMGA2 Is Involved in Phenotype of Cancer Stem Cells}

Cancer stem cells (CSCs) are a minor population of cells that exist in tumor tissues. They have the abilities of self-renewal, differentiation, tumor initiation, and drug resistance [125]. These cells are assumed to persist in tumor tissues as a distinct population that may trigger relapse. HMGA2 has been shown to be involved in cancer stemness in different types of cancers [126-129]. Our recent study demonstrated that HMGA2 and CD133 positively correlate in breast tumors. In this study, we reported that HMGA2 knockdown decreases the number of cancer colonies, as well as reduces the size of mammospheres. We also showed that HMGA2 suppression reduces the population of CD133+ and CD44+ cells [35]. HMGA2 suppression decreases expression of the cancer stem cell markers ALDH, SOX2, and Nanog [130]. Furthermore, HMGA2 expression increases more than 9-fold in CD133-positive population of glioblastoma multiforme (GBM) neurosphere cells compared to CD133-negative cells. In contrast, HMGA2 knockdown reduces GBM stemness [131]. HMGA2 is a specific modulator of neural and embryonic stem cells' (ESCs) self-renewal potentials [31]. HMGA2 directly binds to the SOX2 promotor and regulates the expression of this gene, which encodes an important cancer stem cell marker [132]. In addition, another study demonstrated the positive regulatory role of HMGA2 on the SOX2 function in anaplastic astrocytoma side population cells [129]. A recent study indicated that the lin-28Blet-7-HMGA2 signaling axis controls the high self-renewal potential of fetal hematopoietic stem cells [18]. Additionally, HMGA2 increases the expression of cancer stem cell markers, including CD44, Oct4, and Twist1 [133]. There is a positive correlation between HMGA2 and CD44 in gastric tumors. HMGA2 overexpression increases the gastric cancer sphero- 
cytes, as well as expression of the markers CD44, ALDH1, SOX2, and Oct4 [134]. In contrast, HMGA2 seems to be a negative regulator of both Ink4a and Arf expression. HMGA2 binds to the JunB locus and subsequently promotes Ink4a/Arf expression and self-renewal of stem cells. Restoration of low let-7 expression results in the HMGA2 downregulation and increases Ink4a/Arf, triggering p16INK4a expression in self-renewing cells. Deletion of HMGA2 in mice reduces stem cell numbers and self-renewal. Moreover, p16(Ink4a) and p19(Arf) expression are increased in HMGA2-deficient stem cells [31,135]. HMGA2 promotes self-renewal of neural stem cells (NSCs) by negative regulation of Ink4a/Arf expression [31]. It also regulates expression of FOXM1 and PLAU, which improves selfrenewal and invasiveness of glioma-initiating cells [136]. Yamazaki et al. showed a positive correlation between HMGA2 and BMI-1-1 in head and neck squamous cell carcinoma (HNSCC). BMI-1-1 and HMGA2 promote self-renewal in stem cells via negative regulation of the expression of the tumor suppressors Ink4a and Arf [137]. The proinflammatory signals in M1 macrophages induce stemness properties in nonstem breast cancer cells through STAT3/NF-kB signaling via activation of lin-28B/let-7/HMGA2. It was suggested that suppression of HMGA2 expression directly overturns the proinflammatory signals, inducing the expression of the reprogramming factors Klf-4 and Nanog, repressing mammosphere formation, and reducing the ALDH1+ subpopulation [85]. HMGA2 expression is increased in chemotherapy-naive samples. However, there are no HMGA2 expression differences between chemotherapy-naive and postchemotherapy samples [138]. Finally, in gastric cancers, by targeting both Bcl2 and HMGA2, miR-34a suppresses self-renewal and differentiation [139].

\section{HMGA2 Promotes Angiogenesis during Cancer Development}

Angiogenesis is the formation of new capillaries from pre-existing blood vasculature. It is a crucial mechanism required for a number of pathophysiological events. During tumor growth, angiogenesis is required for delivery of oxygen and nutrients and removal of metabolic waste products from tumor sites [140]. There are data suggesting that HMGA2 may regulate angiogenesis in tumor formation.

It was demonstrated that silencing of HMGA2 reduced the angiogenesis in mouse endothelial progenitor cells, and, conversely, HMGA2 induction enhanced angiogenic functions [141]. In another study, HMGA2 was showed to promote angiogenesis in oral squamous cell carcinoma. The results from HMGA2-bound DNA fragments enriched by ChIP assay confirmed the involvement of HMGA2 in VEGF signaling and TGF-b signaling pathways [142]. In addition, Li et al. showed that HMGA2 increases angiogenesis in leiomyoma cells and myometrial (MM) xenografts via inducing angiogenic factors including VEGFA, EGF, bFGF, TGFa, VEGFR1, and VEGFR2, augments HUVEC tube development, and increases IGF2BP2 and pAKT levels [143]. Xia et al. showed HMGA2, in cooperation with nuclear factor-kB (NF-kB), binds to the AT-rich regulatory region of the IGF2BP2 gene [144].

It was shown that metformin decreases angiogenesis and tumor growth by reducing HMGA2 levels in cervical cancer cells through regulation of miR-142-3p. Metformin was suggested to prevent $m i R-142$ sponging to allow targeting of HMGA2 [145]. It was further reported that $m i R-1249$ suppresses colorectal cancer (CRC) angiogenesis by targeting both VEGFA and HMGA2 through the AKT/mTOR signaling pathway [146]. In another study, let-7 was shown to inhibit angiogenesis by targeting IL-6, HMGA2, and VEGF expression [147]. Thus, together, these results suggest a role for HMGA2 in angiogenesis.

\section{HMGA2 Increases EMT, Invasion, and Metastasis}

During the epithelial-mesenchymal transition (EMT) process, epithelial-like cells lose their polarities and cell-cell adhesion and transdifferentiate into mesenchymal-like cells, thereby gaining invasive and migratory properties. EMT enables cancer cells to metastasize to other organs via blood or lymphatic vessels [148]. EMT starts with alterations of the expression of genes that repress epithelial properties and induces mesenchymal 
features, including reduced E-cadherin levels and increases levels of vimentin, Snail1/2, ZEB1/2, and Twist. It has been shown that HMGA2 induces expression of mesenchymal markers and decreases the expression of epithelial markers, thereby increasing invasion and metastasis $[35,85]$. Furthermore, suppression of HMGA2 in vitro significantly inhibits cancer cell mobility and the expression of EMT hallmark proteins. Below, we discuss the role of HMGA2 in several pathways involved in EMT.

\subsection{The MAPK/ERK Pathway}

The RAF/MEK/ERK pathway, also known as the MAPK pathway, induces HMGA2 expression (Figure 5A). HMGA2 overexpression was found to increase the level of phosphorylated ERK. Additionally, inhibiting the MAPK signaling pathway using the MAPK inhibitor U0126 decreases HMGA2 expression and antagonizes HMGA2-mediated EMT and migration [149]. Watanabe et al. demonstrated that HMGA2 silencing increases Ecadherin and decreases Vimentin levels. Snail is a transcriptional repressor of E-cadherin whose levels decreased after HMGA2 silencing in pancreatic cancer cells (Figure 5B). The authors also suggested that HMGA2 activates the Snail gene promoter by binding to the upstream AT-rich region [70]. In another study, Hawsawi et al. showed that HMGA2 is overexpressed in aggressive prostate cancer cell lines and demonstrated that HMGA2 increases the levels of mesenchymal factors, including Snail, Twist, and vimentin, while decreasing epithelial factors. They further showed that HMGA2 overexpression increases E-cadherin translocation from the cell membrane into the cytoplasm and/or nucleus. Thereby, the cells becoming invasive or metastatic [149,150]. HMGA2 promotes metastasis by induction of osteopontin and CXCR4 [91].

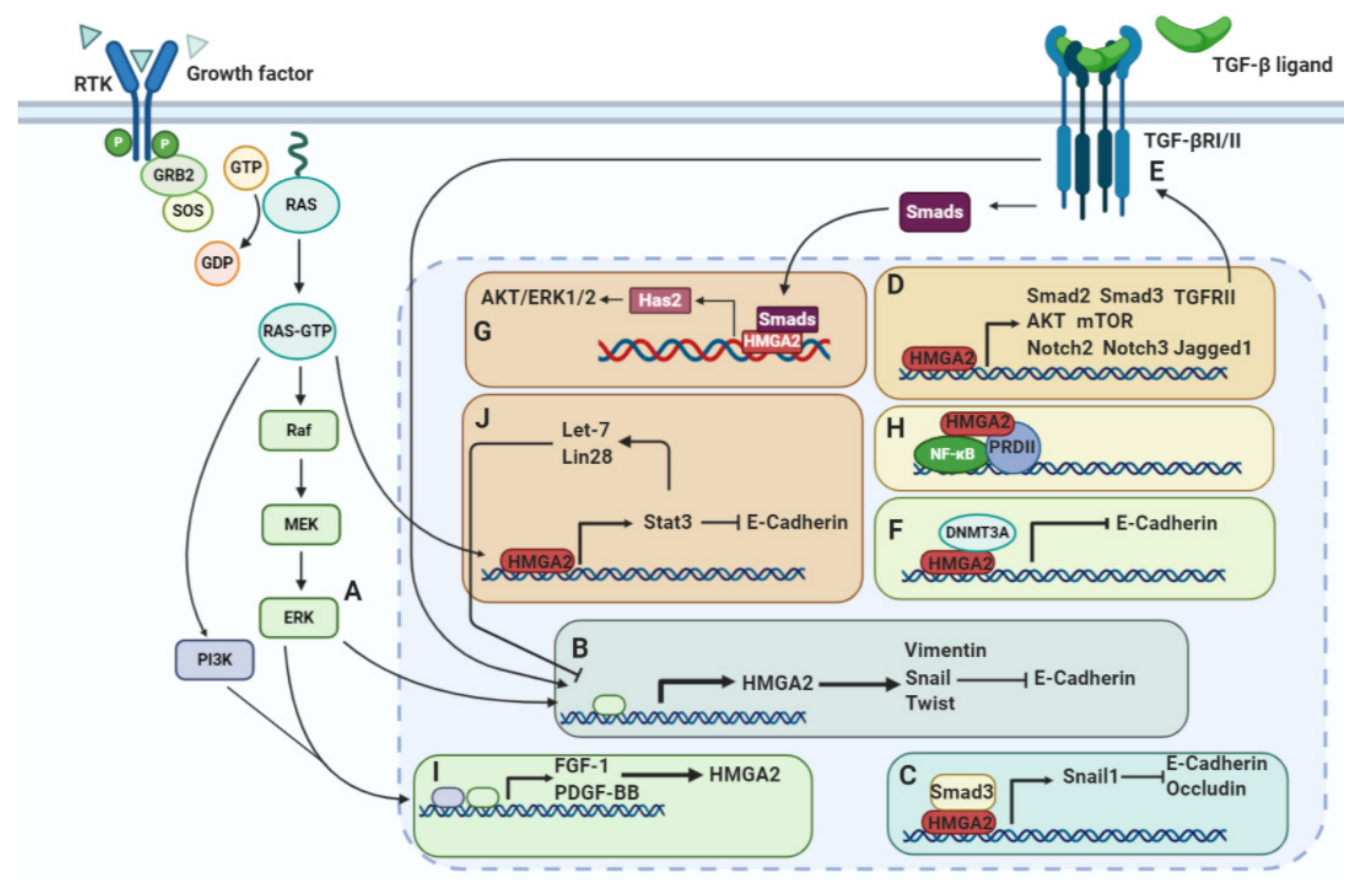

Figure 5. HMGA2 induces EMT by activation of different signaling transducers. (A) HMGA2 expression is induced by the RAF/MEK/ERK pathway. (B) HMGA2 promotes the expression of vimentin, Snail and Twist and reduces E-cadherin expression. (C) Colocalization of HMGA2 and smad 3 on the Snail1 promotor induces expression of Snail1, and then Snail1 inhibits E-cadherin and occludin expression. (D) HMGA2 controls activation of the TGF $\beta$, MAPK, and Notch pathways by regulating the main elements, including Smad2, Smad3, TGF $\beta$ RII, AKT, mTOR, Notch2, Notch3, and Jagged1. (E) TGF $\beta$ RII induced by HMGA2 increases activity of the TGF $\beta$ signaling pathway, which promotes HMGA2 expression in a positive feedback loop. (F) Long-term TGF $\beta$ signaling activation 
causes HMGA2 to recruit DNMT3A to the E-cadherin gene promoter and inactivates its transcription by DNA methylation. (G) During TGF $\beta$ pathway signaling, Smads cooperate with HMGA2 to bind to the Has2 promoter, inducing expression of Has2, which then activates AKT/ERK1/2 signaling. (H) HMGA2 enhances the binding of NFKB to the positive regulatory domain II (PRDII) transcription factor. (I) Regulators downstream of the MAPK and PI3K pathways, including FGF-1 and plateletderived growth factor-BB (PDGF-BB), induce HMGA2 expression. (J) HMGA2 induces the expression of STAT3. Then, STAT3 activation promotes EMT by reducing E-cadherin expression. STAT3 also activates the miRNAs let-7 and lin-28, which suppress HMGA2 expression.

The RAF/MEK/ERK signaling cascade induces HMGA2 expression. Activation of RAF-1 increases HMGA2 expression in Pa-4 ovarian cancer cells [151]. The RAF kinase inhibitor protein (RKIP) suppresses the expression of many prometastatic genes in triple-negative breast cancer (TNBC) cells by reversing the biological activities of HMGA2 [152,153]. RKIP has been shown to suppress the expression of many prometastatic genes in TNBC cells by inhibiting HMGA2 expression in the mammary tumors. It was suggested that RKIP suppresses cell C-C motif chemokine ligand 5 (CCL5) expression, macrophage recruitment, and metastasis via coordinated HMGA2 signaling [154] (Figure 6). The HMGA2/miR-200b/LOX axis plays an important role in the initial stages of breast tumor cell invasion and metastasis. MiR-200 is induced by RKIP and downregulates HMGA2 expression. MiR-200 directly inhibits Lysyl oxidase (LOX) expression, leading to inhibition of breast tumor invasion [91] (Figure 6). Zou et al. suggested that miR-185 targets HMGA2 via the RKIP pathway and inhibits breast cancer cell growth and invasion. They showed that overexpression of RKIP upregulates $m i R-185$ expression and that HMGA2 is one of the targets for this miRNA [155] (Figure 6). In another study, Chen et al. reported that overexpression of RKIP upregulates miR-98 expression and this inhibits glioma cell invasion via targeting of HMGA2 [156] (Figure 6).

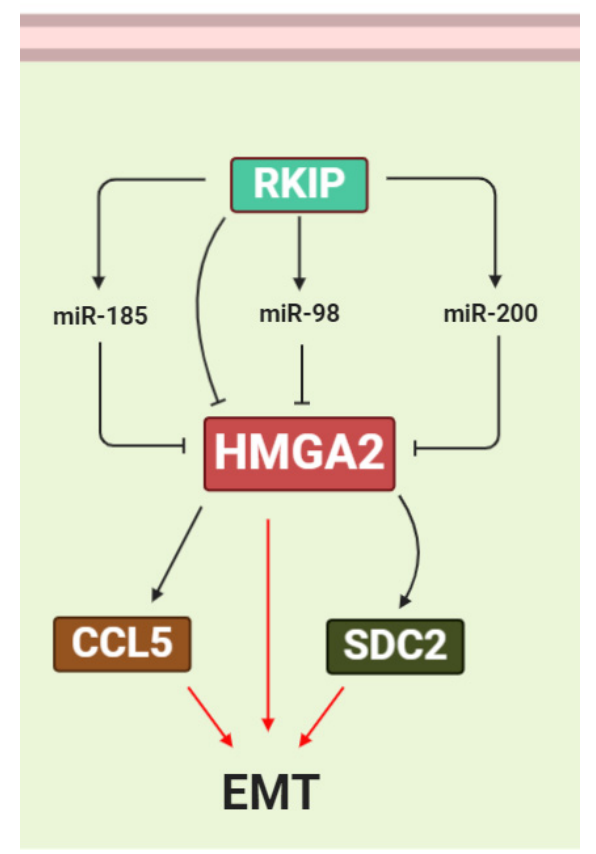

Figure 6. HMGA2 is regulated by the RAF kinase inhibitor protein (RKIP) pathway. RKIP suppresses HMGA2 expression directly, as well as indirectly, by inducing the miRNAs $m i R-185, m i R-200$, and miR-98, which target the $3^{\prime} \mathrm{UTR}$ of HMGA2 mRNA. Suppression of HMGA2 via RKIP and miRNAs reduces the expression of the EMT-promoting factors CCL5 and SDC2. 


\subsection{TGFß/Smad Signaling}

Similar to Snail1 and ZEB1, TGF- $\beta$ also transcriptionally induces HMGA2 expression [157] (Figure 5B). Thuault et al. demonstrated that HMGA2 is induced by the TGF- $\beta$ pathway during the EMT process. They also showed that Smad signaling induces HMGA2 expression, responsible for the aggressiveness of cancer cells; in addition, they reported HMGA2 may regulate expression of Snail, Slug, $\delta$ EF-1/ZEB-1, and SIP-1/ZEB-2 as well as Twist and E-cadherin during EMT [91]. Our recent study demonstrated that HMGA2 suppression inhibits breast cancer EMT by affecting the TGF- $\beta$ pathway and reducing the Smad3 transducer to further reduce Snail1 levels [35]. HMGA2 directly binds to the Snail1 promotor or colocalizes with smad 3 on the Snail1 promotor. In addition, HMGA2 increases the physical interaction between Smad3 and the Snail1 promotor [158] (Figure 5C). Subsequently, Snail1 not only reduces expression of the epithelial-related genes, including E-cadherin, occluding, and coxsackie adenovirus receptors, but also increases expression of mesenchymal-related genes [159]. HMGA2 expression is upregulated by TGF- $\beta$ activation, as shown by lentiviral infection and pharmacological assays. Furthermore, HMGA2 binds to an AT-rich area on the Twist1 promotor and enhances its transcription. Concomitant silencing of Twist1 and Snail1 revert mesenchymal HMGA2-expressing cells to a more epithelial phenotype compared to silencing Snail1 or Twist1 individually [160]. TGF- $\beta$ signaling, via induction of Smads, increases HMGA2 expression. Subsequently, HMGA2 increases Snail and Twist expression by binding to their promotors. Finally, the overexpression of Snail1 and Twist1 increases ZEB1, ZEB2, and Snail2, which causes EMT reprograming. In another study, it was shown that HMGA2 induces Snail2 expression by directly binding to the Snail2 promoter. In addition, silencing of Snail2 reverses HMGA2induced EMT and decreases invasion and migration of colon cancer cells [161]. Hou et al. reported that blocking of EMT using a selective inhibitor of TGF $\beta$ /Smad, TGF $\beta$ /ERK or Notch signaling pathway significantly inhibits HMGA2 protein expression. In addition, HMGA2 silencing impairs TGF 32 -associated phosphorylation of Smad2 and Smad3. In addition, HMGA2 suppression inhibits the upregulation of Jagged1, Notch2, and Notch3 induced by TGF $\beta 2$ [162] (Figure 5D). Long-term TGF $\beta$ signaling activation causes HMGA2 to recruit DNA methyltransferase (DNMT3A) to the E-cadherin gene and silencing of this gene by DNA methylation, thereby increasing the EMT phenotype [163] (Figure 5F).

Kolliopoulos et al. showed that TGF $\beta$ binding to its receptors (T $\beta R I$ and T $\beta R I I$ ) initiates signaling via Smad-dependent and -independent signaling pathways. Smads cooperate with HMGA2, resulting in Has2 transcription and production of hyaluronan. In turn, hyaluronan binds to CD44, triggering the AKT and ERK1/2 signaling pathways, consequently inducing EMT and breast cancer progression [164] (Figure 5G). Moreover, TGF $\beta$ beta receptor 2 (TGF $\beta$ RII), induced by HMGA2, promotes an autocrine TGF $\beta$ signaling feed-forward positive loop in EMT. As HMGA2 increases TGF $\beta$ RII, it activates TGF $\beta$ signaling, increasing HMGA2 expression levels, following which HMGA2 itself promotes TGF signaling [165] (Figure 5E).

\subsection{The PI3K/AKT/mTOR Pathway}

Activation of the PI3K/AKT/mTOR signaling pathway is crucial for EMT processes, which includes cancer cells invasion and migration [166]. Tan et al. reported that HMGA2 silencing decreases proliferation of acute myeloid leukemia cells by reducing phosphorylation of AKT and mTOR (Figure 5D) [93]. The fibroblast growth factor-1 (FGF-1) and platelet-derived growth factor-BB (PDGF-BB) receptors are known to signal through both the MAPK pathway and the PI3K pathway. Ayoubi et al. showed that FGF-1 and PDGFBB can induce HMGA2 expression [167] (Figure 5I). In another study, they showed that treatment of 3T3-L1 cells with the inhibitor of PDGF alpha and beta receptors, Tyrphostin AG1296, results in a strong inhibition of HMGA2 mRNA expression by serum. In addition, treatment of cells with the EGF receptor tyrosine kinase inhibitor Tyrphostin AG1478 leads to a slight inhibition of HMGA2 mRNA expression. The PI3-kinase inhibitors wortmannin and LY294002 significantly inhibit the induction of HMGA2 mRNA by serum [168]. Thus, 
these studies provide strong evidence for the involvement of this pathway in the regulation of HMGA2 expression.

\subsection{The NFאB Pathway}

The first cooperation between the HMGA family and NFKB was reported by Thanos et al. They showed that HMGA1, in conjunction with NFKB, induces IFN- $\beta$ expression in virus infection immunity [169]. Noro et al. showed that HMGA2 physically interacts with the p50/p65 subunits of NF- $\mathrm{KB}$ [170]. HMGA2 is able to enhance the binding of NFKB to the positive regulatory domain II (PRDII) transcription factor (Figure 5H) [171]. It was shown that HMGA2-dependent expression of IMP2 plays an important role during embryonic development and in tumorigenesis. The authors showed that the mRNA expression level of IMP2 increased nearly two-fold in HMGA2-induced cells compared to control cells [172]. Additionally, they showed that the AT-rich regulatory region resides in the first intron of the insulin-like growth factor $2 \mathrm{mRNA}$ binding protein 2 (IGF2BP2/IMP2) gene. The AT-rich regulatory region mimics the response of endogenous IMP2 to HMGA2. This promotes HMGA2 binding both in vitro and in vivo. A consensus NF- $\kappa B$ binding site was identified immediately adjacent to the AT-rich regulatory region that binds to NF- $\mathrm{KB}$. Via this mechanism, NF-kB and HMGA2 cooperate to regulate IMP2 gene expression $[6,173]$.

\subsection{STAT3 Signaling}

Inflammatory cytokines can stimulate EMT by activation of STAT3. STAT3 acts as a transcription factor for Twist, Snail, and ZEB1, increasing their expression by binding to their promoters $[174,175]$. Additionally, ectopic expression of STAT3 suppresses E-cadherin expression in prostate cancer [176]. It was reported that HMGA2 activates STAT3 through the Ras signaling pathway. This is necessary for EMT in salivary epithelial cells [177]. In addition, the miRNAs lin-28 and let-7 have been shown to regulate the STAT3 signaling pathway. Moreover, HMGA2 is one of the targets for let-7. The existence of a dynamic switch mechanism was proposed. This involves a lin-28/let-7/HMGA2 signaling circuit that controls the STAT3-mediated inflammatory response, which may regulate self-renewal and differentiation in cancer stem cells [178] (Figure 5J).

\subsection{HMGA2 Is Involved in Other Signaling Pathways}

It was demonstrated that expression of the oncogenic HMGA2 leads to Ten-eleven translocation methylcytosine dioxygenase 1 (TET1) suppression. TET1 was described as binding and demethylating itself as well as HOXA7 and HOXA9, and reduced TET1 expression level causes TET1 inhibition along with loss of HOXA7 and HOXA9 expression. Suppression of TET1 and HOXA9 promotes breast cancer development and metastasis by increasing oncogenes [179].

One of the key pathways which involves in the initiation and progression of most types of cancers is Hippo-YAP signaling [180]. It was observed that interfering HMGA2 cased YAP protein reduction. Hence, they showed that the effect of HMGA2 on TNBC is related to targeting of YAP. These results showed that HMGA2 could stabilize the YAP protein via impeding its ubiquitination in the proteasome system [181].

\section{HMGA2 Increase Cancer Drug Resistance}

The ability of cancer cells to survive and proliferate even in the presence of anticancer therapeutic agents is called cancer drug resistance. The presence of cancer stem cell populations in tumor tissues promotes the probability of chemotherapy resistance. There are two possible scenarios of cancer drug resistance, including intrinsic resistance and acquired resistance after treatment with chemotherapeutic agents [182]. HMGA2 has been found to promote drug resistance by inherent intrinsic resistance and by inducing cancer stem cell populations. HMGA2 expression correlates with overall survival, as well as with progression-free survival (PFS) of patients who were treated with at least two cycles of cisplatin-based therapy [183]. Currently, it is understood that autophagy is critical in the 
process of cancer drug resistance in a variety of malignant cells [184]. In another study, a contradictory role was reported for HMGA2- Li et al. showed that HMGA2 overexpression suppresses gefitinib resistance in NSCLC cells by inhibiting autophagy [185]. They showed that HMGA2 overexpression decreased LC3B II expression, a key marker of autophagy, and subsequently reduced resistance to gefitinib by inhibiting autophagy.

It was identified that HMGA2 is a downstream target of let-7a to modulate cell proliferation, metastasis, and chemosensitivity to gemcitabine pancreatic cancer cells [186]. miR-509-3 directly targets HMGA2 and RAD51 enhances the sensitivity to Olaparib in ovarian cancer in both in vitro and in vivo experiments [187]. It is suggested that HMGA2, by regulating damage repair factors such as ATR, ATM, and ERCC, may induce resistance to Olaparib. Overexpression of HMGA2 enhances chemoresistance to 5-Fluorouracilfluorouracil (5-FU) via activation of the Wnt pathway in both in vitro and in vivo experiments of colorectal cancer. It was suggested that HMGA2 promotes Dv12 expression, leading to enhanced activation of the Wnt/ $\beta$-catenin pathway [188]. The inhibitory effect of the let-7g on the expression of the HMGA2 was demonstrated in a 5-FU-resistant human hepatoma cell line and it also reduced cyclin A expression, which is the key regulator of $S$ phase and mitosis [189]. Additionally, our previous study showed that HMGA2 silencing using mature specific siRNAs sensitizes breast cancer cells to paclitaxel [190]. Lastly, in colorectal cancer cells, replacement of miR-194 results in this miRNA targeting HMGA2 coexpressed genes through the TGF $\beta$ signaling pathway and this decreases cell viability in response to oxaliplatin and irinotecan [191]. These studies establish that HMGA2 plays an important role in cancer drug resistance by using different biological processes and this may act as a double-edged sword. HMGA2, by inhibiting autophagy, can decrease cancer drug resistance; however, most studies describe the significant role of HMGA2 in drug resistance by increasing cancer stem cell population, increasing DNA damage markers, and activating the Wnt- $\beta$ catenin signaling pathway.

\section{Perspectives and Conclusions}

HMGA2 is a transcriptional regulator essential for embryonic development. Its expression is decreased during postembryonic development. However, HMGA2 levels are often re-expressed during oncogenesis. RNA sequencing analysis on clinical and normal samples has shown that HMGA2 is upregulated in most cancers. HMGA2 induces cancer cell proliferation by promoting entry into the $\mathrm{S}$ phase of the cell cycle. It also inhibits apoptosis and induces DNA repair. In addition, HMGA2 promotes EMT by inducing the MAPK/ERK, TGF $\beta /$ Smad and PI3K/AKT/mTOR/NFKB, and RKIP pathways, as well as regulating miRNA expression. HMGA2 also promotes cancer stem cell properties and induces drug resistance in cancer cells. Overall, HMGA2 may be used as a prognosis cancer marker, especially in aggressive stages of the disease. Additionally, HMGA2 may be a potential cancer therapeutic target. Targeting of HMGA2 via small interfering RNAs (siRNAs) or specific inhibitors including metformin could decrease cancer development, metastasis and drug resistance. In addition to the above-mentioned therapeutic strategies, miRNA replacement therapy has recently attracted significant attention and introducing the miRNAs which target the $3^{\prime}$ UTR region of HMGA2 mRNA, such as those of the let-7 family, may be an attractive approach.

Author Contributions: B.M. determined the main direction and provided significant guidance in the writing of this manuscript. B.M. drafted the manuscript and illustrated the figures for the manuscript. A.M. and V.K. made the figure and the table. H.J.D. and P.H.G.D. reviewed and edited the manuscript. M.F.G. and B.B. supervised, reviewed, and edited the final version of the manuscript. All authors have read and agreed to the published version of the manuscript.

Funding: This work is supported by the Tabriz University of Medical Sciences, grant number (58754).

Institutional Review Board Statement: Not applicable.

Informed Consent Statement: All authors consent to publication. 
Data Availability Statement: Not applicable.

Conflicts of Interest: The authors declare no conflict of interest.

\begin{abstract}
Abbreviations
3'UTR: 3'-Three prime untranslated region, AKT: Protein Kinase B, ALDH: Aldehyde Dehydrogenase, AP: Apurinic/Apyrimidinic, AP1: Activator Protein-1, APE1: AP Endonuclease 1, Arg: Arginine, ATF/CREB: Activating Transcription Factor/cAMP Response Element (CRE)-Binding Protein, ATR: Ataxia Telangiectasia and Rad3-Related Kinase, BAD: BCL2-Associated Agonist of Cell Death, Bcl-2: B-Cell Lymphoma 2, BER: Base Excision Repair, BMI-1: B Lymphoma Mo-MLV Insertion Region 1, BRCA1: Breast Cancer Type 1, cAMP: Cyclic Adenosine Monophosphate, CCL5: C-C Motif Chemokine Ligand 5, CCNB2: Cyclin B2, CDK: Cyclin Dependent Kinase, CHK: Checkpoint Kinase 1, CRE: Cyclic AMP-Responsive Element, CREB: cAMP-Responsive Element Binding Protein, CXCR4: C-X-C Motif Chemokine Receptor 4, DNMT3A: DNA Methyltransferase 3 Alpha, E2F1: E2F Transcription Factor 1, EGF: Epidermal Growth Factor, EMT: Epithelial-Mesenchymal Transition, ERCC1: Excision Repair Cross-Complementation Group, ERK: Extracellular Receptor Kinase, ESC: Embryonic Stem Cell, FGF: Fibroblast Growth Factor, FOS: Fos Proto-Oncogene, FOXM1: Forkhead Box M1, FRA1: FOS-Like 1, GBM: Glioblastoma Multiforme, Gly: Glycine, HDAC1: Histone Deacetylase 1, HMG: High Mobility Group, HMGA2: High Mobility Group Protein 2, HNSCC: Head and Neck Squamous Cell Carcinoma, IGF2BP2: Insulin-Like Growth Factor 2 mRNA Binding Protein 2, IL-6: Interleukin 6, IMP2: Inner Mitochondrial Membrane Peptidase Subunit 2, Ink4a/ Arf: Cyclin Dependent Kinase Inhibitor 2A, JUN: Jun Proto-Oncogene, Ku-80: ATP-Dependent DNA Helicase II 80 KDa Subunit, LC3B: Microtubule-Associated Protein 1 Light Chain 3 Beta, LOX: Lysyl Oxidase, MAPK: Mitogen-Activated Protein Kinase, MEK: Mitogen-Activated Protein Kinase, miRNA: MicroRNA, mTOR: Mechanistic Target of Rapamycin Kinase, MTSS1: MTSS I-BAR Domain Containing 1, NFkB: Nuclear Factor Kappa B, NHEJ: Nonhomologous End-Joining, NSCLC: Nonsmall-cell lung carcinoma, NSC: Neural Stem Cell, Oct4: Octamer-Binding Protein 4, p16INK4a: Cyclin Dependent Kinase Inhibitor 2A, P21CIP1: Cyclin Dependent Kinase Inhibitor 1A, PDGF-BB: Platelet-Derived Growth Factor-BB, PFS: Progression-Free Survival, PI3K: Phosphatidylinositol 3-kinase, PLAU: Plasminogen Activator, Urokinase, pRB: Retinoblastoma Protein, PRDII: Positive Regulatory Domain II, RAD51: DNA Repair Protein RAD51, RAF: Rapidly Accelerated Fibrosarcoma, RKIP: RAF Kinase Inhibitor Protein, SDC2: Syndecan-2, SIP-1: Smad-Interacting Protein-1, siRNA: Small Interfering RNA, SOX2: SRY-Box Transcription Factor 2, STAT3: Signal Transducer and Activator of Transcription 3, TGF $\beta$ : Transforming Growth Factor Beta, TNBC: Triple-Negative Breast Cancer, TNF: Tumor Necrosis Factor, TRAIL-R1: TNF-Related Apoptosis-Inducing Ligand-R2, VEGF: Vascular Endothelial Growth Factor, VEGFA: Vascular Endothelial Growth Factor A, WAF1: Wild-Type p53-Activated Fragment 1, ZEB1/2: Zinc Finger E-box Binding Protein 1/2, $\gamma$-H2AX: Phosphorylated form H2A Histone Family Member X, $\delta$ EF-1: $\delta$-Crystallin/E2-Box Factor 1.
\end{abstract}

\title{
References
}

1. Rajeswari, M.R.; Jain, A. High-mobility-group chromosomal proteins, HMGA1 as potential tumour markers. Curr. Sci. 2002, 82, 838-844.

2. Grosschedl, R.; Giese, K.; Pagel, J. HMG domain proteins: Architectural elements in the assembly of nucleoprotein structures. Trends Genet. 1994, 10, 94-100. [CrossRef]

3. Bustin, M.; Lehn, D.A.; Landsman, D. Structural features of the HMG chromosomal proteins and their genes. Biochim. Biophys. Acta BBA Gene Struct. Expr. 1990, 1049, 231-243. [CrossRef]

4. Elton, T.S.; Reeves, R. Purification and postsynthetic modifications of Friend erythroleukemic cell high mobility group protein HMG-I. Anal. Biochem. 1986, 157, 53-62. [CrossRef]

5. Cui, T.; Leng, F. Specific recognition of AT-rich DNA sequences by the mammalian high mobility group protein AT-hook 2: A SELEX study. Biochemistry 2007, 46, 13059-13066. [CrossRef] [PubMed]

6. Thanos, D.; Maniatis, T. The high mobility group protein HMG I (Y) is required for NF-kB-dependent virus induction of the human IFN- $\beta$ gene. Cell 1992, 71, 777-789. [CrossRef]

7. Ozturk, N.; Singh, I.; Mehta, A.; Braun, T.; Barreto, G. HMGA proteins as modulators of chromatin structure during transcriptional activation. Front Cell Dev. Biol. 2014, 2, 5. [CrossRef] [PubMed] 
8. Xu, M.; Sharma, P.; Pan, S.; Malik, S.; Roeder, R.G.; Martinez, E. Core promoter-selective function of HMGA1 and Mediator in Initiator-dependent transcription. Genes Dev. 2011, 25, 2513-2524. [CrossRef]

9. Read, C.; Cary, P.D.; Crane-Robinson, C.; Driscoll, P.C.; Carrillo, M.; Norman, D.G. The structure of the HMG box and its interaction with DNA. In Nucleic Acids and Molecular Biology; Springer: Berlin/Heidelberg, Germany, 1995; pp. 222-250.

10. Baxevanis, A.D.; Landsman, D. The HMG-1 box protein family: Classification and functional relationships. Nucleic Acids Res. 1995, 23, 1604-1613. [CrossRef]

11. Fedele, M.; Battista, S.; Kenyon, L.; Baldassarre, G.; Fidanza, V.; Klein-Szanto, A.J.; Parlow, A.; Visone, R.; Pierantoni, G.M.; Outwater, E. Overexpression of the HMGA2 gene in transgenic mice leads to the onset of pituitary adenomas. Oncogene 2002, 21, 3190-3198. [CrossRef]

12. Huth, J.R.; Bewley, C.A.; Nissen, M.S.; Evans, J.N.; Reeves, R.; Gronenborn, A.M.; Clore, G.M. The solution structure of an HMG-I (Y)-DNA complex defines a new architectural minor groove binding motif. Nat. Struct. Biol. 1997, 4, 657-665. [CrossRef]

13. Sgarra, R.; Rustighi, A.; Tessari, M.A.; Di Bernardo, J.; Altamura, S.; Fusco, A.; Manfioletti, G.; Giancotti, V. Nuclear phosphoproteins HMGA and their relationship with chromatin structure and cancer. Febs Lett. 2004, 574, 1-8. [CrossRef]

14. Zhou, X.; Benson, K.F.; Ashar, H.R.; Chada, K.J.N. Mutation responsible for the mouse pygmy phenotype in the developmentally regulated factor HMGI-C. Nature 1995, 376, 771-774. [CrossRef] [PubMed]

15. Fedele, M.; Fusco, A. HMGA and cancer. Biochim. Biophys. Acta BBA Gene Regul. Mech. 2010, 1799, 48-54. [CrossRef]

16. Narita, M.; Narita, M.; Krizhanovsky, V.; Nuñez, S.; Chicas, A.; Hearn, S.A.; Myers, M.P.; Lowe, S.W. A novel role for high-mobility group a proteins in cellular senescence and heterochromatin formation. Cell 2006, 126, 503-514. [CrossRef]

17. Schoenmakers, E.F.; Wanschura, S.; Mols, R.; Bullerdiek, J.; Van den Berghe, H.; Van de Ven, W.J. Recurrent rearrangements in the high mobility group protein gene, HMGI-C, in benign mesenchymal tumours. Nat. Genet. 1995, 10, 436-444. [CrossRef]

18. Nishino, J.; Kim, I.; Chada, K.; Morrison, S.J.J.C. HMGA2 promotes neural stem cell self-renewal in young but not old mice by reducing p16Ink4a and p19Arf Expression. Cell 2008, 135, 227-239. [CrossRef] [PubMed]

19. Rogalla, P.; Drechsler, K.; Frey, G.; Hennig, Y.; Helmke, B.; Bonk, U.; Bullerdiek, J.J.T.A. HMGI-C expression patterns in human tissues. Implications for the genesis of frequent mesenchymal tumors. Am. J. Pathol. 1996, 149, 775. [PubMed]

20. Ashar, H.R.; Chouinard, R.A., Jr.; Dokur, M.; Chada, K. In vivo modulation of HMGA2 expression. Am. J. Pathol. 2010, 1799, 55-61. [CrossRef] [PubMed]

21. Goodwin, G. Molecules in focus The high mobility group protein, HMGI-C. Int. J. Biochem. Cell Biol. 1998, 30, 761-766. [CrossRef]

22. Henriksen, J.; Stabell, M.; Meza-Zepeda, L.A.; Lauvrak, S.A.; Kassem, M.; Myklebost, O.J.B. Identification of target genes for wild type and truncated HMGA2 in mesenchymal stem-like cells. Biochim. Biophys. Acta BBA Gene Regul. Mech. 2010, 10, 329. [CrossRef]

23. Fedele, M.; Berlingieri, M.T.; Scala, S.; Chiariotti, L.; Viglietto, G.; Rippel, V.; Bullerdiek, J.; Santoro, M.; Fusco, A. Truncated and chimeric HMGI-C genes induce neoplastic transformation of NIH3T3 murine fibroblasts. Oncogene 1998, 17, $413-418$. [CrossRef] [PubMed]

24. Zaidi, M.R.; Okada, Y.; Chada, K.K. Misexpression of full-length HMGA2 induces benign mesenchymal tumors in mice. Cancer Res. 2006, 66, 7453-7459. [CrossRef]

25. Wood, L.J.; Maher, J.F.; Bunton, T.E.; Resar, L.M. The oncogenic properties of the HMG-I gene family. Cancer Res. 2000, 60, 4256-4261. [PubMed]

26. Lee, Y.S.; Dutta, A. The tumor suppressor microRNA let-7 represses the HMGA2 oncogene. Genes Dev. 2007, 21, 1025-1030. [CrossRef]

27. Chirshev, E.A.; Nguyen, A.; Nozomi, H.; Alyse, H.; Unternaehrer, J. Micro-Rna Let-7 Regulation and Function in Ovarian Cancer and Early Embryonic Development. Clin. Cancer Res. 2019, 152. [CrossRef]

28. Mansoori, B.; Mohammadi, A.; Naghizadeh, S.; Gjerstorff, M.; Shanehbandi, D.; Shirjang, S.; Najafi, S.; Holmskov, U.; Khaze, V.; Duijf, P.H.G.; et al. miR-330 suppresses EMT and induces apoptosis by downregulating HMGA2 in human colorectal cancer. $J$. Cell. Physiol. 2020, 235, 920-931. [CrossRef]

29. Qiu, K.; Xie, Q.; Jiang, S.; Lin, T. miR-98-5p promotes apoptosis and inhibits migration and cell growth in papillary thyroid carcinoma through Bax/Caspase-3 by HMGA2. J. Clin. Lab. Anal. 2020, 34, e23044. [CrossRef]

30. Wu, S.; Ai, H.; Zhang, K.; Yun, H.; Xie, F. Long Non-Coding RNA EGOT Promotes the Malignant Phenotypes of Hepatocellular Carcinoma Cells and Increases the Expression of HMGA2 via Down-Regulating miR-33a-5p. Oncotargets Ther. 2019, 12, 11623-11635. [CrossRef]

31. Mansoori, B.; Mohammadi, A.; Asadzadeh, Z.; Shirjang, S.; Minouei, M.; Abedi Gaballu, F.; Shajari, N.; Kazemi, T.; Gjerstorff, M.F.; Duijf, P.H. HMGA2 and Bach-1 cooperate to promote breast cancer cell malignancy. J. Cell. Physiol. 2019, 234, 17714-17726. [CrossRef]

32. Zhou, Z.G.; Xu, C.; Dong, Z.; Wang, Y.P.; Duan, J.Y.; Yan, C.Q. MiR-497 inhibits cell proliferation and invasion ability by targeting HMGA2 in pancreatic ductal adenocarcinoma. Eur. Rev. Med. Pharmacol. Sci. 2020, 24, 122-129. [CrossRef] [PubMed]

33. Liu, Z.; Lü, Y.; Jiang, Q.; Yang, Y.; Dang, C.; Sun, R. miR-491 inhibits BGC-823 cell migration via targeting HMGA2. Int. J. Biol. Markers 2019, 34, 364-372. [CrossRef] [PubMed]

34. Gao, X.; Dai, M.; Li, Q.; Wang, Z.; Lu, Y.; Song, Z. HMGA 2 regulates lung cancer proliferation and metastasis. Thorac. Cancer 2017, 8, 501-510. [CrossRef] [PubMed] 
35. Mansoori, B.; Duijf, P.H.G.; Mohammadi, A.; Najafi, S.; Roshani, E.; Shanehbandi, D.; Hajiasgharzadeh, K.; Shirjang, S.; Ditzel, H.J.; Kazemi, T.; et al. Overexpression of HMGA2 in breast cancer promotes cell proliferation, migration, invasion and stemness. Expert Opin. Targets 2020, 1-11. [CrossRef] [PubMed]

36. Malek, A.; Bakhidze, E.; Noske, A.; Sers, C.; Aigner, A.; Schäfer, R.; Tchernitsa, O. HMGA2 gene is a promising target for ovarian cancer silencing therapy. Int. J. Cancer 2008, 123, 348-356. [CrossRef] [PubMed]

37. Dyrskjøt, L.; Thykjaer, T.; Kruhøffer, M.; Jensen, J.L.; Marcussen, N.; Hamilton-Dutoit, S.; Wolf, H.; Ørntoft, T.F. Identifying distinct classes of bladder carcinoma using microarrays. Nat. Genet. 2003, 33, 90-96. [CrossRef] [PubMed]

38. Pomeroy, S.L.; Tamayo, P.; Gaasenbeek, M.; Sturla, L.M.; Angelo, M.; McLaughlin, M.E.; Kim, J.Y.; Goumnerova, L.C.; Black, P.M.; Lau, C. Prediction of central nervous system embryonal tumour outcome based on gene expression. Nature 2002, 415, 436-442. [CrossRef]

39. Ma, X.-J.; Dahiya, S.; Richardson, E.; Erlander, M.; Sgroi, D.C. Gene expression profiling of the tumor microenvironment during breast cancer progression. Breast Cancer Res. 2009, 11, R7. [CrossRef]

40. Finak, G.; Bertos, N.; Pepin, F.; Sadekova, S.; Souleimanova, M.; Zhao, H.; Chen, H.; Omeroglu, G.; Meterissian, S.; Omeroglu, A. Stromal gene expression predicts clinical outcome in breast cancer. Nat. Med. 2008, 14, 518-527. [CrossRef] [PubMed]

41. Skrzypczak, M.; Goryca, K.; Rubel, T.; Paziewska, A.; Mikula, M.; Jarosz, D.; Pachlewski, J.; Oledzki, J.; Ostrowsk, J. Modeling oncogenic signaling in colon tumors by multidirectional analyses of microarray data directed for maximization of analytical reliability. PLoS ONE 2010, 5, e13091. [CrossRef]

42. Hu, N.; Clifford, R.J.; Yang, H.H.; Wang, C.; Goldstein, A.M.; Ding, T.; Taylor, P.R.; Lee, M.P. Genome wide analysis of DNA copy number neutral loss of heterozygosity $(\mathrm{CNNLOH})$ and its relation to gene expression in esophageal squamous cell carcinoma. BMC Genom. 2010, 11, 576. [CrossRef]

43. Su, H.; Hu, N.; Yang, H.H.; Wang, C.; Takikita, M.; Wang, Q.-H.; Giffen, C.; Clifford, R.; Hewitt, S.M.; Shou, J.-Z. Global gene expression profiling and validation in esophageal squamous cell carcinoma and its association with clinical phenotypes. Clin. Cancer Res. 2011, 17, 2955-2966. [CrossRef]

44. Chen, X.; Leung, S.Y.; Yuen, S.T.; Chu, K.-M.; Ji, J.; Li, R.; Chan, A.S.; Law, S.; Troyanskaya, O.G.; Wong, J. Variation in gene expression patterns in human gastric cancers. Mol. Biol. Cell 2003, 14, 3208-3215. [CrossRef]

45. Giordano, T.J.; Au, A.Y.; Kuick, R.; Thomas, D.G.; Rhodes, D.R.; Wilhelm, K.G.; Vinco, M.; Misek, D.E.; Sanders, D.; Zhu, Z. Delineation, functional validation, and bioinformatic evaluation of gene expression in thyroid follicular carcinomas with the PAX8-PPARG translocation. Clin. Cancer Res. 2006, 12, 1983-1993. [CrossRef] [PubMed]

46. Vasko, V.; Espinosa, A.V.; Scouten, W.; He, H.; Auer, H.; Liyanarachchi, S.; Larin, A.; Savchenko, V.; Francis, G.L.; de la Chapelle, A. Gene expression and functional evidence of epithelial-to-mesenchymal transition in papillary thyroid carcinoma invasion. Proc. Natl. Acad. Sci. USA 2007, 104, 2803-2808. [CrossRef] [PubMed]

47. Ye, H.; Yu, T.; Temam, S.; Ziober, B.L.; Wang, J.; Schwartz, J.L.; Mao, L.; Wong, D.T.; Zhou, X. Transcriptomic dissection of tongue squamous cell carcinoma. BMC Genom. 2008, 9, 69. [CrossRef] [PubMed]

48. He, H.; Jazdzewski, K.; Li, W.; Liyanarachchi, S.; Nagy, R.; Volinia, S.; Calin, G.A.; Liu, C.-g.; Franssila, K.; Suster, S. The role of microRNA genes in papillary thyroid carcinoma. Proc. Natl. Acad. Sci. USA 2005, 102, 19075-19080. [CrossRef]

49. Toruner, G.A.; Ulger, C.; Alkan, M.; Galante, A.T.; Rinaggio, J.; Wilk, R.; Tian, B.; Soteropoulos, P.; Hameed, M.R.; Schwalb, M.N. Association between gene expression profile and tumor invasion in oral squamous cell carcinoma. Cancer Genet. Cytogenet. 2004, 154, 27-35. [CrossRef]

50. Ginos, M.A.; Page, G.P.; Michalowicz, B.S.; Patel, K.J.; Volker, S.E.; Pambuccian, S.E.; Ondrey, F.G.; Adams, G.L.; Gaffney, P.M. Identification of a gene expression signature associated with recurrent disease in squamous cell carcinoma of the head and neck. Cancer Res. 2004, 64, 55-63. [CrossRef] [PubMed]

51. Pyeon, D.; Newton, M.A.; Lambert, P.F.; Den Boon, J.A.; Sengupta, S.; Marsit, C.J.; Woodworth, C.D.; Connor, J.P.; Haugen, T.H.; Smith, E.M. Fundamental differences in cell cycle deregulation in human papillomavirus-positive and human papillomavirusnegative head/neck and cervical cancers. Cancer Res. 2007, 67, 4605-4619. [CrossRef]

52. Sengupta, S.; Den Boon, J.A.; Chen, I.-H.; Newton, M.A.; Dahl, D.B.; Chen, M.; Cheng, Y.-J.; Westra, W.H.; Chen, C.-J.; Hildesheim, A. Genome-wide expression profiling reveals EBV-associated inhibition of MHC class I expression in nasopharyngeal carcinoma. Cancer Res. 2006, 66, 7999-8006. [CrossRef]

53. Valk, P.J.; Verhaak, R.G.; Beijen, M.A.; Erpelinck, C.A.; van Doorn-Khosrovani, S.B.v.W.; Boer, J.M.; Beverloo, H.B.; Moorhouse, M.J.; Van Der Spek, P.J.; Löwenberg, B. Prognostically useful gene-expression profiles in acute myeloid leukemia. N. Engl. J. Med. 2004, 350, 1617-1628. [CrossRef]

54. Su, L.-J.; Chang, C.-W.; Wu, Y.-C.; Chen, K.-C.; Lin, C.-J.; Liang, S.-C.; Lin, C.-H.; Whang-Peng, J.; Hsu, S.-L.; Chen, C.-H. Selection of DDX5 as a novel internal control for Q-RT-PCR from microarray data using a block bootstrap re-sampling scheme. BMC Genom. 2007, 8, 140. [CrossRef] [PubMed]

55. Okayama, H.; Kohno, T.; Ishii, Y.; Shimada, Y.; Shiraishi, K.; Iwakawa, R.; Furuta, K.; Tsuta, K.; Shibata, T.; Yamamoto, S. Identification of genes upregulated in ALK-positive and EGFR/KRAS/ALK-negative lung adenocarcinomas. Cancer Res. 2012, 72, 100-111. [CrossRef] [PubMed]

56. Garber, M.E.; Troyanskaya, O.G.; Schluens, K.; Petersen, S.; Thaesler, Z.; Pacyna-Gengelbach, M.; Van De Rijn, M.; Rosen, G.D.; Perou, C.M.; Whyte, R.I. Diversity of gene expression in adenocarcinoma of the lung. Proc. Natl. Acad. Sci. USA 2001, 98, 13784-13789. [CrossRef] 
57. Hou, J.; Aerts, J.; Den Hamer, B.; Van Ijcken, W.; Den Bakker, M.; Riegman, P.; van der Leest, C.; van der Spek, P.; Foekens, J.A.; Hoogsteden, H.C. Gene expression-based classification of non-small cell lung carcinomas and survival prediction. PLOS ONE 2010, 5, e10312. [CrossRef] [PubMed]

58. Compagno, M.; Lim, W.K.; Grunn, A.; Nandula, S.V.; Brahmachary, M.; Shen, Q.; Bertoni, F.; Ponzoni, M.; Scandurra, M.; Califano, A. Mutations of multiple genes cause deregulation of NF-kB in diffuse large B-cell lymphoma. Nature 2009, 459, 717-721. [CrossRef] [PubMed]

59. Riker, A.I.; Enkemann, S.A.; Fodstad, O.; Liu, S.; Ren, S.; Morris, C.; Xi, Y.; Howell, P.; Metge, B.; Samant, R.S. The gene expression profiles of primary and metastatic melanoma yields a transition point of tumor progression and metastasis. BMC Med Genom. 2008, 1, 13. [CrossRef]

60. Pei, H.; Li, L.; Fridley, B.L.; Jenkins, G.D.; Kalari, K.R.; Lingle, W.; Petersen, G.; Lou, Z.; Wang, L. FKBP51 affects cancer cell response to chemotherapy by negatively regulating Akt. Cancer Cell 2009, 16, 259-266. [CrossRef]

61. Magee, J.A.; Araki, T.; Patil, S.; Ehrig, T.; True, L.; Humphrey, P.A.; Catalona, W.J.; Watson, M.A.; Milbrandt, J. Expression profiling reveals hepsin overexpression in prostate cancer. Cancer Res. 2001, 61, 5692-5696.

62. LaTulippe, E.; Satagopan, J.; Smith, A.; Scher, H.; Scardino, P.; Reuter, V.; Gerald, W.L. Comprehensive gene expression analysis of prostate cancer reveals distinct transcriptional programs associated with metastatic disease. Cancer Res. 2002, 62, $4499-4506$.

63. Singh, D.; Febbo, P.G.; Ross, K.; Jackson, D.G.; Manola, J.; Ladd, C.; Tamayo, P.; Renshaw, A.A.; D’Amico, A.V.; Richie, J.P. Gene expression correlates of clinical prostate cancer behavior. Cancer Cell 2002, 1, 203-209. [CrossRef]

64. Barretina, J.; Taylor, B.S.; Banerji, S.; Ramos, A.H.; Lagos-Quintana, M.; DeCarolis, P.L.; Shah, K.; Socci, N.D.; Weir, B.A.; Ho, A. Subtype-specific genomic alterations define new targets for soft-tissue sarcoma therapy. Nat. Genet. 2010, $42,715$. [CrossRef] [PubMed]

65. Mansoori, B.; Mohammadi, A.; Shirjang, S.; Baradaran, B. HMGI-C suppressing induces P53/caspase9 axis to regulate apoptosis in breast adenocarcinoma cells. Cell Cycle 2016, 15, 2585-2592. [CrossRef]

66. Kumar, M.S.; Armenteros-Monterroso, E.; East, P.; Chakravorty, P.; Matthews, N.; Winslow, M.M.; Downward, J. HMGA2 functions as a competing endogenous RNA to promote lung cancer progression. Nature 2014, 505, 212-217. [CrossRef]

67. Meyer, B.; Loeschke, S.; Schultze, A.; Weigel, T.; Sandkamp, M.; Goldmann, T.; Vollmer, E.; Bullerdiek, J. HMGA2 overexpression in non-small cell lung cancer. Mol. Carcinog. Publ. Coop. Univ. Tex. Anderson Cancer Cent. 2007, 46, 503-511. [CrossRef]

68. Wu, J.; Zhang, S.; Shan, J.; Hu, Z.; Liu, X.; Chen, L.; Ren, X.; Yao, L.; Sheng, H.; Li, L. Elevated HMGA2 expression is associated with cancer aggressiveness and predicts poor outcome in breast cancer. Cancer Lett. 2016, 376, 284-292. [CrossRef]

69. Wang, X.; Liu, X.; Li, A.Y.-J.; Chen, L.; Lai, L.; Lin, H.H.; Hu, S.; Yao, L.; Peng, J.; Loera, S. Overexpression of HMGA2 promotes metastasis and impacts survival of colorectal cancers. Clin. Cancer Res. 2011, 17, 2570-2580. [CrossRef]

70. Watanabe, S.; Ueda, Y.; Akaboshi, S.-i.; Hino, Y.; Sekita, Y.; Nakao, M. HMGA2 maintains oncogenic RAS-induced epithelialmesenchymal transition in human pancreatic cancer cells. Am. J. Pathol. 2009, 174, 854-868. [CrossRef]

71. Zha, L.; Zhang, J.; Tang, W.; Zhang, N.; He, M.; Guo, Y.; Wang, Z. HMGA2 elicits EMT by activating the Wnt/ $\beta$-catenin pathway in gastric cancer. Dig. Dis. Sci. 2013, 58, 724-733. [CrossRef] [PubMed]

72. Zhu, C.; Li, J.; Cheng, G.; Zhou, H.; Tao, L.; Cai, H.; Li, P.; Cao, Q.; Ju, X.; Meng, X.; et al. miR-154 inhibits EMT by targeting HMGA2 in prostate cancer cells. Mol. Cell Biochem. 2013, 379, 69-75. [CrossRef]

73. Yang, G.; Zhang, L.; Bo, J.; Hou, K.; Cai, X.; Chen, Y.; Li, H.; Liu, D.; Huang, Y. Overexpression of HMGA2 in bladder cancer and its association with clinicopathologic features and prognosis: HMGA2 as a prognostic marker of bladder cancer. Eur. J. Surg. Oncol. 2011, 37, 265-271. [CrossRef]

74. Zhao, X.-P.; Zhang, H.; Jiao, J.-Y.; Tang, D.-X.; Wu, Y.-1.; Pan, C.-B. Overexpression of HMGA2 promotes tongue cancer metastasis through EMT pathway. J. Transl. Med. 2016, 14, 26. [CrossRef] [PubMed]

75. Fedele, M.; Visone, R.; De Martino, I.; Troncone, G.; Palmieri, D.; Battista, S.; Ciarmiello, A.; Pallante, P.; Arra, C.; Melillo, R.M. HMGA2 induces pituitary tumorigenesis by enhancing E2F1 activity. Cancer Cell 2006, 9, 459-471. [CrossRef]

76. Belge, G.; Meyer, A.; Klemke, M.; Burchardt, K.; Stern, C.; Wosniok, W.; Loeschke, S.; Bullerdiek, J. Upregulation of HMGA2 in thyroid carcinomas: A novel molecular marker to distinguish between benign and malignant follicular neoplasias. Genes Chromosomes Cancer 2008, 47, 56-63. [CrossRef]

77. Xia, Y.-y.; Yin, L.; Jiang, N.; Guo, W.-J.; Tian, H.; Jiang, X.-S.; Wu, J.; Chen, M.; Wu, J.-Z.; He, X. Downregulating HMGA2 attenuates epithelial-mesenchymal transition-induced invasion and migration in nasopharyngeal cancer cells. Biochem. Biophys. Res. Commun. 2015, 463, 357-363. [CrossRef]

78. Mansoori, B.; Mohammadi, A.; Shirjang, S.; Baradaran, B. Micro-RNAs: The new potential biomarkers in cancer diagnosis, prognosis and cancer therapy. Cell. Mol. Biol.Noisy Grand Fr. 2015, 61, 1-10.

79. Mansoori, B.; Mohammadi, A.; Shirjang, S.; Baradaran, B. MicroRNAs in the diagnosis and treatment of cancer. Immunol. Investig. 2017, 46, 880-897. [CrossRef] [PubMed]

80. Winkler, S.; Murua Escobar, H.; Meyer, B.; Simon, D.; Eberle, N.; Baumgartner, W.; Loeschke, S.; Nolte, I.; Bullerdiek, J. HMGA2 expression in a canine model of prostate cancer. Cancer Genet Cytogenet 2007, 177, 98-102. [CrossRef]

81. De Martino, I.; Visone, R.; Fedele, M.; Petrocca, F.; Palmieri, D.; Hoyos, J.M.; Forzati, F.; Croce, C.M.; Fusco, A. Regulation of microRNA expression by HMGA1 proteins. Oncogene 2016, 35, 5817-5818. [CrossRef] 
82. Jiang, W.; Gu, W.; Qiu, R.; He, S.; Shen, C.; Wu, Y.; Zhang, J.; Zhou, J.; Guo, Y.; Wan, D. miRNA-101 suppresses epithelialto-mesenchymal transition by targeting HMGA2 in pancreatic cancer cells. Anti Cancer Agents Med. Chem. 2016, 16, 432-439. [CrossRef] [PubMed]

83. Zhu, M.; Zhang, C.; Chen, D.; Chen, S.; Zheng, H. MicroRNA-98-HMGA2-POSTN signal pathway reverses epithelial-tomesenchymal transition in laryngeal squamous cell carcinoma. Biomed. Pharmacother. Biomed. Pharmacother. 2019, $117,108998$. [CrossRef] [PubMed]

84. Ma, J.; Li, D.; Kong, F.F.; Yang, D.; Yang, H.; Ma, X.X. miR-302a-5p/367-3p-HMGA2 axis regulates malignant processes during endometrial cancer development. J. Exp. Clin. Cancer Res. 2018, 37, 19. [CrossRef] [PubMed]

85. Chen, X.; Zeng, K.; Xu, M.; Liu, X.; Hu, X.; Xu, T.; He, B.; Pan, Y.; Sun, H.; Wang, S. P53-induced miR-1249 inhibits tumor growth, metastasis, and angiogenesis by targeting VEGFA and HMGA2. Cell Death Dis. 2019, 10, 131. [CrossRef] [PubMed]

86. Kang, N.N.; Ge, S.L.; Zhang, R.Q.; Huang, Y.L.; Liu, S.D.; Wu, K.M. MiR-490-3p inhibited the proliferation and metastasis of esophageal squamous cell carcinoma by targeting HMGA2. Eur. Rev. Med Pharmacol. Sci. 2018, 22, 8298-8305. [CrossRef]

87. Mei, L.-L.; Wang, W.-J.; Qiu, Y.-T.; Xie, X.-F.; Bai, J.; Shi, Z.-Z. miR-125b-5p functions as a tumor suppressor gene partially by regulating HMGA2 in esophageal squamous cell carcinoma. PLoS ONE 2017, 12, e0185636. [CrossRef]

88. Chen, Z.; Li, Q.; Wang, S.; Zhang, J. miR-485-5p inhibits bladder cancer metastasis by targeting HMGA2. Int. J. Mol. Med. 2015, 36, 1136-1142. [CrossRef]

89. Rice, S.J.; Lai, S.C.; Wood, L.W.; Helsley, K.R.; Runkle, E.A.; Winslow, M.M.; Mu, D. MicroRNA-33a mediates the regulation of high mobility group AT-hook 2 gene (HMGA2) by thyroid transcription factor 1 (TTF-1/NKX2-1). J. Biol. Chem. 2013, 288, 16348-16360. [CrossRef]

90. Zhang, P.; Bai, H.; Liu, G.; Wang, H.; Chen, F.; Zhang, B.; Zeng, P.; Wu, C.; Peng, C.; Huang, C.; et al. MicroRNA-33b, upregulated by EF24, a curcumin analog, suppresses the epithelial-to-mesenchymal transition (EMT) and migratory potential of melanoma cells by targeting HMGA2. Toxicol. Lett. 2015, 234, 151-161. [CrossRef]

91. Sun, M.; Gomes, S.; Chen, P.; Frankenberger, C.A.; Sankarasharma, D.; Chung, C.H.; Chada, K.K.; Rosner, M.R. RKIP and HMGA2 regulate breast tumor survival and metastasis through lysyl oxidase and syndecan-2. Oncogene 2014, 33, 3528-3537. [CrossRef] [PubMed]

92. Wu, J.; Wei, J.-J. HMGA2 and high-grade serous ovarian carcinoma. J. Mol. Med. 2013, 91, 1155-1165. [CrossRef]

93. Tan, L.; Wei, X.; Zheng, L.; Zeng, J.; Liu, H.; Yang, S.; Tan, H. Amplified HMGA2 promotes cell growth by regulating Akt pathway in AML. J. Cancer Res. Clin. Oncol. 2016, 142, 389-399. [CrossRef]

94. Esmailzadeh, S.; Mansoori, B.; Mohammadi, A.; Shanehbandi, D.; Baradaran, B. siRNA-mediated silencing of HMGA2 induces apoptosis and cell cycle arrest in human colorectal carcinoma. J. Gastrointest. Cancer 2017, 48, 156-163. [CrossRef] [PubMed]

95. Tessari, M.A.; Gostissa, M.; Altamura, S.; Sgarra, R.; Rustighi, A.; Salvagno, C.; Caretti, G.; Imbriano, C.; Mantovani, R.; Del Sal, G. Transcriptional activation of the cyclin A gene by the architectural transcription factor HMGA2. Mol. Cell. Biol. 2003, 23, 9104-9116. [CrossRef]

96. Li, Y.; Peng, L.; Seto, E. Histone deacetylase 10 regulates the cell cycle g2/m phase transition via a novel let-7-HMGA2-cyclin a2 pathway. Mol. Cell. Biol. 2015, 35, 3547-3565. [CrossRef]

97. Shaulian, E.; Karin, M. AP-1 as a regulator of cell life and death. Nat. Cell Biol. 2002, 4, E131-E136. [CrossRef] [PubMed]

98. Vallone, D.; Battista, S.; Pierantoni, G.M.; Fedele, M.; Casalino, L.; Santoro, M.; Viglietto, G.; Fusco, A.; Verde, P. Neoplastic transformation of rat thyroid cells requires the junB and fra-1 gene induction which is dependent on the HMGI-C gene product. EMBO J. 1997, 16, 5310-5321. [CrossRef]

99. Evan, G.I.; Brown, L.; Whyte, M.; Harrington, E. Apoptosis and the cell cycle. Curr. Opin. Cell Biol. 1995, 7, 825-834. [CrossRef]

100. Seville, L.L.; Shah, N.; Westwell, A.D.; Chan, W.C. Modulation of pRB/E2F functions in the regulation of cell cycle and in cancer. Curr. Cancer Drug Targets 2005, 5, 159-170. [CrossRef] [PubMed]

101. Yu, K.-R.; Park, S.-B.; Jung, J.-W.; Seo, M.-S.; Hong, I.-S.; Kim, H.-S.; Seo, Y.; Kang, T.-W.; Lee, J.Y.; Kurtz, A. HMGA2 regulates the in vitro aging and proliferation of human umbilical cord blood-derived stromal cells through the mTOR/p70S6K signaling pathway. Stem Cell Res. 2013, 10, 156-165. [CrossRef]

102. Topacio, B.R.; Zatulovskiy, E.; Cristea, S.; Xie, S.; Tambo, C.S.; Rubin, S.M.; Sage, J.; Kõivomägi, M.; Skotheim, J.M. Cyclin D-Cdk4,6 Drives Cell-Cycle Progression via the Retinoblastoma Protein's C-Terminal Helix. Mol. Cell 2019, 74, 758-770.e4. [CrossRef]

103. Zhang, H.; Tang, Z.; Deng, C.; He, Y.; Wu, F.; Liu, O.; Hu, C. HMGA 2 is associated with the aggressiveness of tongue squamous cell carcinoma. Oral Dis. 2017, 23, 255-264. [CrossRef] [PubMed]

104. Xie, H.; Wang, J.; Jiang, L.; Geng, C.; Li, Q.; Mei, D.; Zhao, L.; Cao, J. ROS-dependent HMGA2 upregulation mediates Cd-induced proliferation in MRC-5 cells. Toxicol. Vitr. 2016, 34, 146-152. [CrossRef]

105. Minshull, J.; Blow, J.J.; Hunt, T. Translation of cyclin mRNA is necessary for extracts of activated Xenopus eggs to enter mitosis. Cell 1989, 56, 947-956. [CrossRef]

106. Liu, W.; Tan, L.; Xiong, X.; Liang, Y.; Tan, H. The effects of lentivirus-mediated RNA interference silencing HMGA2 on proliferation and expressions of cyclin B2 and cyclin A2 in HL-60 cells. Zhonghua Xue Ye Xue Za Zhi Zhonghua Xueyexue Zazhi 2012, 33, 448-452. [PubMed]

107. Pentimalli, F.; Dentice, M.; Fedele, M.; Pierantoni, G.M.; Cito, L.; Pallante, P.; Santoro, M.; Viglietto, G.; Dal Cin, P.; Fusco, A. Suppression of HMGA2 protein synthesis could be a tool for the therapy of well differentiated liposarcomas overexpressing HMGA2. Cancer Res. 2003, 63, 7423-7427. [CrossRef] 
108. Kaur, H.; Hütt-Cabezas, M.; Weingart, M.F.; Xu, J.; Kuwahara, Y.; Erdreich-Epstein, A.; Weissman, B.E.; Eberhart, C.G.; Raabe, E.H. The chromatin-modifying protein HMGA2 promotes atypical teratoid/rhabdoid cell tumorigenicity. J. Neuropathol. Exp. Neurol. 2015, 74, 177-185. [CrossRef]

109. Basolo, F.; Fiore, L.; Fusco, A.; Giannini, R.; Albini, A.; Merlo, G.R.; Fontanini, G.; Conaldi, P.G.; Toniolo, A. Potentiation of the malignant phenotype of the undifferentiated ARO thyroid cell line by insertion of the bcl-2 gene. Int. J. Cancer 1999, 81, 956-962. [CrossRef]

110. Sos, M.L.; Fischer, S.; Ullrich, R.; Peifer, M.; Heuckmann, J.M.; Koker, M.; Heynck, S.; Stückrath, I.; Weiss, J.; Fischer, F. Identifying genotype-dependent efficacy of single and combined PI3K-and MAPK-pathway inhibition in cancer. Proc. Natl. Acad. Sci. USA 2009, 106, 18351-18356. [CrossRef]

111. Cardone, M.H.; Roy, N.; Stennicke, H.R.; Salvesen, G.S.; Franke, T.F.; Stanbridge, E.; Frisch, S.; Reed, J.C. Regulation of cell death protease caspase-9 by phosphorylation. Science 1998, 282, 1318-1321. [CrossRef] [PubMed]

112. Wang, X.-T.; Pei, D.-S.; Xu, J.; Guan, Q.-H.; Sun, Y.-F.; Liu, X.-M.; Zhang, G.-Y. Opposing effects of Bad phosphorylation at two distinct sites by Akt1 and JNK1/2 on ischemic brain injury. Cell. Signal. 2007, 19, 1844-1856. [CrossRef]

113. Wei, C.-H.; Wei, L.-X.; Lai, M.-Y.; Chen, J.-Z.; Mo, X.-J. Effect of silencing of high mobility group A2 gene on gastric cancer MKN-45 cells. World J. Gastroenterol. 2013, 19, 1239. [CrossRef]

114. Wang, W.-Y.; Cao, Y.-X.; Zhou, X.; Wei, B.; Zhan, L.; Fu, L.-T. HMGA2 gene silencing reduces epithelial-mesenchymal transition and lymph node metastasis in cervical cancer through inhibiting the ATR/Chk1 signaling pathway. Am. J. Transl. Res. 2018, 10, 3036. [PubMed]

115. Haselmann, V.; Kurz, A.; Bertsch, U.; Hübner, S.; Olempska-Müller, M.; Fritsch, J.; Häsler, R.; Pickl, A.; Fritsche, H.; Annewanter, F. Nuclear death receptor TRAIL-R2 inhibits maturation of let-7 and promotes proliferation of pancreatic and other tumor cells. Gastroenterology 2014, 146, 278-290. [CrossRef]

116. Danial, N.N.; Korsmeyer, S.J. Cell death: Critical control points. Cell 2004, 116, 205-219. [CrossRef]

117. Shi, X.; Tian, B.; Ma, W.; Zhang, N.; Qiao, Y.; Li, X.; Zhang, Y.; Huang, B.; Lu, J. A novel anti-proliferative role of HMGA2 in induction of apoptosis through caspase 2 in primary human fibroblast cells. Biosci. Rep. 2015, 35, e00169. [CrossRef] [PubMed]

118. Fujikane, R.; Komori, K.; Sekiguchi, M.; Hidaka, M. Function of high-mobility group A proteins in the DNA damage signaling for the induction of apoptosis. Sci. Rep. 2016, 6, 1-9. [CrossRef]

119. Summer, H.; Li, O.; Bao, Q.; Zhan, L.; Peter, S.; Sathiyanathan, P.; Henderson, D.; Klonisch, T.; Goodman, S.D.; Dröge, P. HMGA2 exhibits dRP / AP site cleavage activity and protects cancer cells from DNA-damage-induced cytotoxicity during chemotherapy. Nucleic Acids Res. 2009, 37, 4371-4384. [CrossRef]

120. Cleynen, I.; Van de Ven, W.J. The HMGA proteins: A myriad of functions (Review). Int. J. Oncol. 2008, 32, 289-305. [CrossRef]

121. Li, A.Y.J.; Boo, L.M.; Wang, S.-Y.; Lin, H.H.; Wang, C.C.C.; Yen, Y.; Chen, B.P.C.; Chen, D.J.; Ann, D.K. Suppression of nonhomologous end joining repair by overexpression of HMGA2. Cancer Res. 2009, 69, 5699-5706. [CrossRef]

122. Palmieri, D.; Valentino, T.; D’angelo, D.; De Martino, I.; Postiglione, I.; Pacelli, R.; Croce, C.; Fedele, M.; Fusco, A. HMGA proteins promote ATM expression and enhance cancer cell resistance to genotoxic agents. Oncogene 2011, 30, 3024-3035. [CrossRef]

123. Natarajan, S.; Hombach-Klonisch, S.; Dröge, P.; Klonisch, T. HMGA2 inhibits apoptosis through interaction with ATR-CHK1 signaling complex in human cancer cells. Neoplasia 2013, 15, 263-280. [CrossRef]

124. Wang, B.; Pan, L.Y.; Kang, N.; Shen, X.Y. PP4R1 interacts with HMGA2 to promote non-small-cell lung cancer migration and metastasis via activating MAPK/ERK-induced epithelial-mesenchymal transition. Mol. Carcinog. 2020, 59, 467-477. [CrossRef]

125. Borrmann, L.; Schwanbeck, R.; Heyduk, T.; Seebeck, B.; Rogalla, P.; Bullerdiek, J.; Wisniewski, J.R. High mobility group A2 protein and its derivatives bind a specific region of the promoter of DNA repair gene ERCC1 and modulate its activity. Nucleic Acids Res. 2003, 31, 6841-6851. [CrossRef]

126. Liu, Z.; Liu, J.; Segura, M.F.; Shao, C.; Lee, P.; Gong, Y.; Hernando, E.; Wei, J.J. MiR-182 overexpression in tumourigenesis of high-grade serous ovarian carcinoma. J. Pathol. 2012, 228, 204-215. [CrossRef]

127. Sreepadmanabh, M.; Toley, B.J. Investigations into the cancer stem cell niche using in-vitro 3-D tumor models and microfluidics. Biotechnol. Adv. 2018, 36, 1094-1110. [CrossRef] [PubMed]

128. Kaur, H.; Guo, H.; Green, P.; Akhtarkhavari, S.; Shah, S.; Eberhart, C.G.; Raabe, E.H. Targeting the Fatal Pediatric Brain Tumors AT/RT and DIPG with the DNA Binding Agent Quinacrine; AACR: Philadelphia, PA, USA, 2019.

129. Kaur, H.; Guo, H.; Akhtarkhavari, S.; Eberhart, C.; Raabe, E. HGG-25. Targeting the epigenetic modifier HMGA2 in dipg and high grade gliomas inhibits proliferation, invasion and tumorigenicity. Neuro Oncol. 2019, 21, ii92. [CrossRef]

130. Kaur, H.; Guo, H.; Eberhart, C.G.; Raabe, E.H. Targeting the Lethal Pediatric Atypical Teratoid/Rhabdoid Tumors with the DNA Minor-Groove Binding Agent Quinacrine; AACR: Philadelphia, PA, USA, 2018.

131. Yang, M.Y.; Chen, M.T.; Huang, P.I.; Wang, C.Y.; Chang, Y.C.; Yang, Y.P.; Lo, W.L.; Sung, W.H.; Liao, Y.W.; Lee, Y.Y.; et al. Nuclear Localization Signal-Enhanced Polyurethane-Short Branch Polyethylenimine-Mediated Delivery of Let-7a Inhibited Cancer StemLike Properties by Targeting the 3'-UTR of HMGA2 in Anaplastic Astrocytoma. Cell Transplant. 2015, 24, 1431-1450. [CrossRef]

132. Kaur, H.; Ali, S.Z.; Huey, L.; Hütt-Cabezas, M.; Taylor, I.; Mao, X.-g.; Weingart, M.; Chu, Q.; Rodriguez, F.J.; Eberhart, C.G. The transcriptional modulator HMGA2 promotes stemness and tumorigenicity in glioblastoma. Cancer Lett. 2016, 377, 55-64. [CrossRef] [PubMed]

133. Chiou, G.-Y.; Chien, C.-S.; Wang, M.-L.; Chen, M.-T.; Yang, Y.-P.; Yu, Y.-L.; Chien, Y.; Chang, Y.-C.; Shen, C.-C.; Chio, C.-C. Epigenetic regulation of the miR142-3p/interleukin-6 circuit in glioblastoma. Mol. Cell 2013, 52, 693-706. [CrossRef] [PubMed] 
134. Copley, M.R.; Babovic, S.; Benz, C.; Knapp, D.J.; Beer, P.A.; Kent, D.G.; Wohrer, S.; Treloar, D.Q.; Day, C.; Rowe, K. The Lin28b-let7-HMGA2 axis determines the higher self-renewal potential of fetal haematopoietic stem cells. Nat. Cell Biol. 2013, 15, 916-925. [CrossRef] [PubMed]

135. Li, W.; Wang, Z.; Zha, L.; Kong, D.; Liao, G.; Li, H. HMGA2 regulates epithelial-mesenchymal transition and the acquisition of tumor stem cell properties through TWIST1 in gastric cancer. Oncol. Rep. 2017, 37, 185-192. [CrossRef]

136. Sun, J.; Sun, B.; Zhu, D.; Zhao, X.; Zhang, Y.; Dong, X.; Che, N.; Li, J.; Liu, F.; Zhao, N.; et al. HMGA2 regulates CD44 expression to promote gastric cancer cell motility and sphere formation. Am. J. Cancer Res. 2017, 7, 260-274. [PubMed]

137. Yu, F.; Yao, H.; Zhu, P.; Zhang, X.; Pan, Q.; Gong, C.; Huang, Y.; Hu, X.; Su, F.; Lieberman, J. let-7 regulates self renewal and tumorigenicity of breast cancer cells. Cell 2007, 131, 1109-1123. [CrossRef]

138. Zhong, X.; Liu, X.; Li, Y.; Cheng, M.; Wang, W.; Tian, K.; Mu, L.; Zeng, T.; Liu, Y.; Jiang, X. HMGA2 sustains self-renewal and invasiveness of glioma-initiating cells. Oncotarget 2016, 7, 44365. [CrossRef] [PubMed]

139. Yamazaki, H.; Mori, T.; Yazawa, M.; Maeshima, A.M.; Matsumoto, F.; Yoshimoto, S.; Ota, Y.; Kaneko, A.; Tsuda, H.; Kanai, Y. Stem cell self-renewal factors Bmi1 and HMGA2 in head and neck squamous cell carcinoma: Clues for diagnosis. Lab. Investig. 2013, 93, 1331-1338. [CrossRef] [PubMed]

140. Guo, L.; Cheng, X.; Chen, H.; Chen, C.; Xie, S.; Zhao, M.; Liu, D.; Deng, Q.; Liu, Y.; Wang, X. Induction of breast cancer stem cells by M1 macrophages through Lin-28B-let-7-HMGA2 axis. Cancer Lett. 2019, 452, 213-225. [CrossRef] [PubMed]

141. Hetland, T.E.; Holth, A.; Kærn, J.; Flørenes, V.A.; Tropé, C.G.; Davidson, B. HMGA2 protein expression in ovarian serous carcinoma effusions, primary tumors, and solid metastases. Virchows Arch. 2012, 460, 505-513. [CrossRef] [PubMed]

142. Ji, Q.; Hao, X.; Meng, Y.; Zhang, M.; DeSano, J.; Fan, D.; Xu, L. Restoration of tumor suppressor miR-34 inhibits human p53-mutant gastric cancer tumorspheres. BMC Cancer 2008, 8, 266. [CrossRef]

143. Tonini, T.; Rossi, F.; Claudio, P.P. Molecular basis of angiogenesis and cancer. Oncogene 2003, 22, 6549-6556. [CrossRef]

144. Zhu, S.; Deng, S.; Ma, Q.; Zhang, T.; Jia, C.; Zhuo, D.; Yang, F.; Wei, J.; Wang, L.; Dykxhoorn, D.M.; et al. MicroRNA-10A* and MicroRNA-21 modulate endothelial progenitor cell senescence via suppressing high-mobility group A2. Circ. Res. 2013, 112, 152-164. [CrossRef]

145. Sakata, J.; Hirosue, A.; Yoshida, R.; Kawahara, K.; Matsuoka, Y.; Yamamoto, T.; Nakamoto, M.; Hirayama, M.; Takahashi, N.; Nakamura, T.; et al. HMGA2 Contributes to Distant Metastasis and Poor Prognosis by Promoting Angiogenesis in Oral Squamous Cell Carcinoma. Int. J. Mol. Sci. 2019, 20, 2473. [CrossRef]

146. Li, Y.; Qiang, W.; Griffin, B.B.; Gao, T.; Chakravarti, D.; Bulun, S.; Kim, J.J.; Wei, J.J. HMGA2-mediated tumorigenesis through angiogenesis in leiomyoma. Fertil. Steril. 2020, 114, 1085-1096. [CrossRef] [PubMed]

147. Xie, J.; Ubango, J.; Ban, Y.; Chakravarti, D.; Kim, J.J.; Wei, J.J. Comparative analysis of AKT and the related biomarkers in uterine leiomyomas with MED12, HMGA2, and FH mutations. Genes Chromosomes Cancer 2018, 57, 485-494. [CrossRef]

148. Xia, C.; Liang, S.; He, Z.; Zhu, X.; Chen, R.; Chen, J. Metformin, a first-line drug for type 2 diabetes mellitus, disrupts the MALAT1/miR-142-3p sponge to decrease invasion and migration in cervical cancer cells. Eur. J. Pharmacol. 2018, 830, 59-67. [CrossRef]

149. Wu, T.; Jia, J.; Xiong, X.; He, H.; Bu, L.; Zhao, Z.; Huang, C.; Zhang, W. Increased expression of Lin28B associates with poor prognosis in patients with oral squamous cell carcinoma. PLoS ONE 2013, 8, e83869. [CrossRef] [PubMed]

150. Kalluri, R.; Weinberg, R.A. The basics of epithelial-mesenchymal transition. J. Clin. Investig. 2009, 119, 1420-1428. [CrossRef] [PubMed]

151. Ding, X.; Wang, Y.; Ma, X.; Guo, H.; Yan, X.; Chi, Q.; Li, J.; Hou, Y.; Wang, C. Expression of HMGA2 in bladder cancer and its association with epithelial-to-mesenchymal transition. Cell Prolif. 2014, 47, 146-151. [CrossRef]

152. Hawsawi, O.; Henderson, V.; Burton, L.J.; Dougan, J.; Nagappan, P.; Odero-Marah, V. High mobility group A2 (HMGA2) promotes EMT via MAPK pathway in prostate cancer. Biochem. Biophys. Res. Commun. 2018, 504, 196-202. [CrossRef]

153. Elston, M.S.; Gill, A.J.; Conaglen, J.V.; Clarkson, A.; Cook, R.J.; Little, N.S.; Robinson, B.G.; Clifton-Bligh, R.J.; McDonald, K.L. Nuclear accumulation of e-cadherin correlates with loss of cytoplasmic membrane staining and invasion in pituitary adenomas. $J$. Clin. Endocrinol. Metab. 2009, 94, 1436-1442. [CrossRef] [PubMed]

154. Li, D.; Lin, H.H.; McMahon, M.; Ma, H.; Ann, D.K. Oncogenic raf-1 induces the expression of non-histone chromosomal architectural protein HMGI-C via a p44/p42 mitogen-activated protein kinase-dependent pathway in salivary epithelial cells. J. Biol. Chem. 1997, 272, 25062-25070. [CrossRef]

155. Dangi-Garimella, S.; Yun, J.; Eves, E.M.; Newman, M.; Erkeland, S.J.; Hammond, S.M.; Minn, A.J.; Rosner, M.R. Raf kinase inhibitory protein suppresses a metastasis signalling cascade involving LIN28 and let-7. EMBO J. 2009, 28, $347-358$. [CrossRef] [PubMed]

156. Yun, J.; Frankenberger, C.A.; Kuo, W.L.; Boelens, M.C.; Eves, E.M.; Cheng, N.; Liang, H.; Li, W.H.; Ishwaran, H.; Minn, A.J. Signalling pathway for RKIP and Let-7 regulates and predicts metastatic breast cancer. EMBO J. 2011, 30, $4500-4514$. [CrossRef] [PubMed]

157. Frankenberger, C.; Rabe, D.; Bainer, R.; Sankarasharma, D.; Chada, K.; Krausz, T.; Gilad, Y.; Becker, L.; Rosner, M.R. Metastasis suppressors regulate the tumor microenvironment by blocking recruitment of prometastatic tumor-associated macrophages. Cancer Res. 2015, 75, 4063-4073. [CrossRef]

158. Zou, Q.; Wu, H.; Fu, F.; Yi, W.; Pei, L.; Zhou, M. RKIP suppresses the proliferation and metastasis of breast cancer cell lines through up-regulation of miR-185 targeting HMGA2. Arch. Biochem. Biophys. 2016, 610, 25-32. [CrossRef] [PubMed] 
159. Chen, Z.; Cheng, Q.; Ma, Z.; Xi, H.; Peng, R.; Jiang, B. Overexpression of RKIP inhibits cell invasion in glioma cell lines through upregulation of miR-98. Biomed. Res. Int. 2013, 2013, 695179. [CrossRef]

160. Moustakas, A.; Heldin, C.-H. Induction of epithelial-mesenchymal transition by transforming growth factor $\beta$. In Seminars in Cancer Biology; Academic Press: Cambridge, MA, USA, 2012; pp. 446-454.

161. Thuault, S.; Valcourt, U.; Petersen, M.; Manfioletti, G.; Heldin, C.-H.; Moustakas, A. Transforming growth factor- $\beta$ employs HMGA2 to elicit epithelial-mesenchymal transition. J. Cell Biol. 2006, 174, 175-183. [CrossRef] [PubMed]

162. Thuault, S.; Tan, E.-J.; Peinado, H.; Cano, A.; Heldin, C.-H.; Moustakas, A. HMGA2 and Smads co-regulate SNAIL1 expression during induction of epithelial-to-mesenchymal transition. J. Biol. Chem. 2008, 283, 33437-33446. [CrossRef]

163. Vincent, T.; Neve, E.P.; Johnson, J.R.; Kukalev, A.; Rojo, F.; Albanell, J.; Pietras, K.; Virtanen, I.; Philipson, L.; Leopold, P.L. A SNAIL1-SMAD3/ 4 transcriptional repressor complex promotes TGF- $\beta$ mediated epithelial-mesenchymal transition. Nat. Cell Biol. 2009, 11, 943-950. [CrossRef] [PubMed]

164. Tan, E.-J.; Thuault, S.; Caja, L.; Carletti, T.; Heldin, C.-H.; Moustakas, A. Regulation of transcription factor Twist expression by the DNA architectural protein high mobility group A2 during epithelial-to-mesenchymal transition. J. Biol. Chem. 2012, 287, 7134-7145. [CrossRef]

165. Li, Y.; Zhao, Z.; Xu, C.; Zhou, Z.; Zhu, Z.; You, T. HMGA2 induces transcription factor Slug expression to promote epithelial-tomesenchymal transition and contributes to colon cancer progression. Cancer Lett. 2014, 355, 130-140. [CrossRef]

166. Hou, M.; Bao, X.; Luo, F.; Chen, X.; Liu, L.; Wu, M. HMGA2 Modulates the TGF $\beta /$ Smad, TGF $\beta /$ ERK and Notch Signaling Pathways in Human Lens Epithelial-Mesenchymal Transition. Curr. Mol. Med. 2018, 18, 71-82. [CrossRef]

167. Tan, E.-J.; Kahata, K.; Idås, O.; Thuault, S.; Heldin, C.-H.; Moustakas, A. The high mobility group A2 protein epigenetically silences the Cdh1 gene during epithelial-to-mesenchymal transition. Nucleic Acids Res. 2015, 43, 162-178. [CrossRef] [PubMed]

168. Kolliopoulos, C.; Lin, C.Y.; Heldin, C.H.; Moustakas, A.; Heldin, P. Has2 natural antisense RNA and HMGA2 promote Has2 expression during TGF $\beta$-induced EMT in breast cancer. Matrix Biol. J. Int. Soc. Matrix Biol. 2019, 80, 29-45. [CrossRef] [PubMed]

169. Morishita, A.; Zaidi, M.R.; Mitoro, A.; Sankarasharma, D.; Szabolcs, M.; Okada, Y.; D'Armiento, J.; Chada, K. HMGA2 is a driver of tumor metastasis. Cancer Res. 2013, 73, 4289-4299. [CrossRef]

170. Yuan, T.; Cantley, L. PI3K pathway alterations in cancer: Variations on a theme. Oncogene 2008, 27, 5497-5510. [CrossRef]

171. Ayoubi, T.A.; Jansen, E.; Meulemans, S.M.; Van de Ven, W.J. Regulation of HMGIC expression: An architectural transcription factor involved in growth control and development. Oncogene 1999, 18, 5076-5087. [CrossRef] [PubMed]

172. Levitzki, A. Targeting signal transduction for disease therapy. Curr. Opin. Cell Biol. 1996, 8, 239-244. [CrossRef]

173. Noro, B.; Licheri, B.; Sgarra, R.; Rustighi, A.; Tessari, M.A.; Chau, K.-Y.; Ono, S.J.; Giancotti, V.; Manfioletti, G. Molecular dissection of the architectural transcription factor HMGA2. Biochemistry 2003, 42, 4569-4577. [CrossRef]

174. Mantovani, F.; Covaceuszach, S.; Rustighi, A.; Sgarra, R.; Heath, C.; Goodwin, G.H.; Manfioletti, G. NF-kappaB mediated transcriptional activation is enhanced by the architectural factor HMGI-C. Nucleic Acids Res. 1998, 26, 1433-1439. [CrossRef] [PubMed]

175. Fujii, Y.; Kishi, Y.; Gotoh, Y. IMP2 regulates differentiation potentials of mouse neocortical neural precursor cells. Genes Cells Devoted Mol. Cell. Mech. 2013, 18, 79-89. [CrossRef]

176. Cleynen, I.; Brants, J.R.; Peeters, K.; Deckers, R.; Debiec-Rychter, M.; Sciot, R.; Van de Ven, W.J.; Petit, M.M. HMGA2 regulates transcription of the Imp2 gene via an intronic regulatory element in cooperation with nuclear factor-kappaB. Mol. Cancer Res. 2007, 5, 363-372. [CrossRef] [PubMed]

177. Brants, J.R.; Ayoubi, T.A.; Chada, K.; Marchal, K.; Van de Ven, W.J.; Petit, M.M. Differential regulation of the insulin-like growth factor II mRNA-binding protein genes by architectural transcription factor HMGA2. FEBS Lett 2004, 569, 277-283. [CrossRef]

178. Sullivan, N.; Sasser, A.; Axel, A.E.; Vesuna, F.; Raman, V.; Ramirez, N.; Oberyszyn, T.; Hall, B. Interleukin-6 induces an epithelial-mesenchymal transition phenotype in human breast cancer cells. Oncogene 2009, 28, 2940-2947. [CrossRef]

179. Cheng, G.Z.; Zhang, W.; Sun, M.; Wang, Q.; Coppola, D.; Mansour, M.; Xu, L.; Costanzo, C.; Cheng, J.Q.; Wang, L.-H. Twist is transcriptionally induced by activation of STAT3 and mediates STAT3 oncogenic function. J. Biol. Chem. 2008, 283, 14665-14673. [CrossRef]

180. Azare, J.; Leslie, K.; Al-Ahmadie, H.; Gerald, W.; Weinreb, P.H.; Violette, S.M.; Bromberg, J. Constitutively activated Stat3 induces tumorigenesis and enhances cell motility of prostate epithelial cells through integrin $\beta 6$. Mol. Cell. Biol. 2007, 27, 4444-4453. [CrossRef]

181. Zentner, M.D.; Lin, H.H.; Deng, H.-T.; Kim, K.-J.; Shih, H.-M.; Ann, D.K. Requirement for high mobility group protein HMGI-C interaction with STAT3 inhibitor PIAS3 in repression of $\alpha$-subunit of epithelial Na+ channel ( $\alpha$-ENaC) transcription by Ras activation in salivary epithelial cells. J. Biol. Chem. 2001, 276, 29805-29814. [CrossRef] [PubMed]

182. Guo, L.; Chen, C.; Shi, M.; Wang, F.; Chen, X.; Diao, D.; Hu, M.; Yu, M.; Qian, L.; Guo, N. Stat3-coordinated Lin-28-let-7-HMGA2 and miR-200-ZEB1 circuits initiate and maintain oncostatin M-driven epithelial-mesenchymal transition. Oncogene 2013, 32, 5272-5282. [CrossRef]

183. Sun, M.; Song, C.-X.; Huang, H.; Frankenberger, C.A.; Sankarasharma, D.; Gomes, S.; Chen, P.; Chen, J.; Chada, K.K.; He, C.; et al. HMGA2/TET1/HOXA9 signaling pathway regulates breast cancer growth and metastasis. Proc. Natl. Acad. Sci. USA 2013, 110, 9920-9925. [CrossRef] [PubMed]

184. Zhang, L.; Yang, S.; Chen, X.; Stauffer, S.; Yu, F.; Lele, S.M.; Fu, K.; Datta, K.; Palermo, N.; Chen, Y.; et al. The hippo pathway effector YAP regulates motility, invasion, and castration-resistant growth of prostate cancer cells. Mol. Cell Biol. 2015, 35, 1350-1362. [CrossRef] 
185. Xu, J.; Fang, X.; Long, L.; Wang, S.; Qian, S.; Lyu, J. HMGA2 promotes breast cancer metastasis by modulating Hippo-YAP signaling pathway. Cancer Biol. Ther. 2021, 22, 5-11. [CrossRef] [PubMed]

186. Alfarouk, K.O.; Stock, C.M.; Taylor, S.; Walsh, M.; Muddathir, A.K.; Verduzco, D.; Bashir, A.H.; Mohammed, O.Y.; Elhassan, G.O.; Harguindey, S.; et al. Resistance to cancer chemotherapy: Failure in drug response from ADME to P-gp. Cancer Cell Int. 2015, 15, 71. [CrossRef] [PubMed]

187. Krafft, U.; Tschirdewahn, S.; Hess, J.; Harke, N.N.; Hadaschik, B.; Olah, C.; Krege, S.; Nyirády, P.; Szendröi, A.; Szücs, M.; et al. Validation of survivin and HMGA2 as biomarkers for cisplatin resistance in bladder cancer. Urol. Oncol. 2019, 37, 810.e7-810.e15. [CrossRef]

188. Li, X.; Zhou, Y.; Li, Y.; Yang, L.; Ma, Y.; Peng, X.; Yang, S.; Liu, J.; Li, H. Autophagy: A novel mechanism of chemoresistance in cancers. Biomed. Pharmacother. Biomed. Pharmacother. 2019, 119, 109415. [CrossRef]

189. Li, W.; Wang, H.; Yang, Y.; Zhao, T.; Zhang, Z.; Tian, Y.; Shi, Z.; Peng, X.; Li, F.; Feng, Y.; et al. Integrative Analysis of Proteome and Ubiquitylome Reveals Unique Features of Lysosomal and Endocytic Pathways in Gefitinib-Resistant Non-Small Cell Lung Cancer Cells. Proteomics 2018, 18, e1700388. [CrossRef] [PubMed]

190. Xiao, G.; Wang, X.; Yu, Y. CXCR4/Let-7a Axis Regulates Metastasis and Chemoresistance of Pancreatic Cancer Cells Through Targeting HMGA2. Cell. Physiol. Biochem. Int. J. Exp. Cell. Physiol. Biochem. Pharmacol. 2017, 43, 840-851. [CrossRef] [PubMed]

191. Sun, C.; Cao, W.; Qiu, C.; Li, C.; Dongol, S.; Zhang, Z.; Dong, R.; Song, K.; Yang, X.; Zhang, Q. MiR-509-3 augments the synthetic lethality of PARPi by regulating HR repair in PDX model of HGSOC. J. Hematol. Oncol. 2020, 13, 9. [CrossRef] 